\title{
Polymorphism, Composition, and Structural Variability in Topology in 1D, 2D, and 3D Copper Phosphonocarboxylate Materials
}

\author{
Seema Lodhia ${ }^{\dagger}$ Adele Turner, ${ }^{\dagger}$ Maria Papadaki, ${ }^{\ddagger}$ Konstantinos D. Demadis, ${ }^{*}{ }^{\ddagger}$ and \\ Gary B. Hix ${ }^{*}{ }^{\dagger}$
}

School of Science and Technology, Nottingham Trent University, Clifton Lane,

Nottingham, NG11 8NS, United Kingdom, and Crystal Engineering, Growth and Design Laboratory,

Department of Chemistry, University of Crete, Voutes, Heraklion, Crete, GR-71003, Greece

Received September 5, 2008; Revised Manuscript Received January 6, 2009

\begin{abstract}
The syntheses and structural characterization of 1D, 2D, and 3D materials based on copper phosphonocarboxylate backbones are described. More specifically, the synthesis of materials from diethylphosphonoacetic acid (DEPAA) or the close variant hydroxyphosphonoacetic acid (HPAA) and water-soluble $\mathrm{Cu}^{2+}$ salts has been studied. The initial synthesis involving copper acetate and DEPAA was carried out at $160{ }^{\circ} \mathrm{C}$ under hydrothermal conditions and a $\mathrm{Cu}: \mathrm{P}$ ratio of 1:1 resulted in the formation of a mixture of products with the same composition, $\mathrm{Cu}_{1.5}\left(\mathrm{O}_{3} \mathrm{PCH}_{2} \mathrm{CO}_{2}\right) \cdot \mathrm{H}_{2} \mathrm{O}$. Compound $\mathbf{1}$, which is blue in color and crystallizes in the triclinic space group $P \overline{1}$, has a layered structure. Compound $\mathbf{2}$, which is green in color and crystallizes in the monoclinic space group $P 2_{1} / c$, has a three-dimensional structure. Reduction of the reaction temperature to $140{ }^{\circ} \mathrm{C}$ results in the exclusive formation of the $\alpha$-phase (1), while an increase in the reaction temperature to $180{ }^{\circ} \mathrm{C}$ yields a pure sample of 2 . A Cu:P ratio of 2:3 in a reaction at $180{ }^{\circ} \mathrm{C}$ yields a third, related phase, $\mathrm{Cu}\left(\mathrm{HO}_{3} \mathrm{PCH}_{2} \mathrm{CO}_{2}\right) \cdot \mathrm{H}_{2} \mathrm{O}, \mathbf{3}$, which is again triclinic but has a chain-like structure. Finally, reaction of copper chloride and HPAA in a Cu:P ratio of $1: 1$ at room temperature yields one-dimensional $\mathrm{Cu}(R, S-$ $\left.\left.\mathrm{HO}_{3} \mathrm{PCH}(\mathrm{OH}) \mathrm{CO}_{2}\right)\left(\mathrm{H}_{2} \mathrm{O}\right)_{2}\right] \cdot \mathrm{H}_{2} \mathrm{O}, 4$, that incorporates both $R$ and $S$ HPAA stereoisomers. All materials were studied by single crystal $\mathrm{X}$-ray crystallography, X-ray powder diffraction, TGA, FT-IR, and elemental analyses.
\end{abstract}

\section{Introduction}

The synthesis and structural characterization of metal phosphonates (general formula $\mathrm{M}^{n+}\left(\mathrm{O}_{3} \mathrm{PR}\right)_{n / 2} \cdot m \mathrm{~S}$ have become areas of increased interest in recent years (where $\mathrm{M}$ is a metal cation at oxidation state $n+, \mathrm{R}$ is an organic moiety, $\mathrm{S}$ is a solvent molecule, frequently water, and $m$ is the number of lattice solvent molecules). Work in our laboratories and others has dispelled the notion that these materials can only be formed as layered materials, with porous materials being reported that contain $\mathrm{R}$ groups such as $-\mathrm{CH}_{2} \mathrm{OH},{ }^{1}-\mathrm{CH}_{2} \mathrm{CH}\left(\mathrm{NH}_{3}{ }^{+}\right) \mathrm{COO}^{-},{ }^{2}$ $-\left(\mathrm{CH}_{2}\right)_{2} \mathrm{CH}\left(\mathrm{NH}_{3}{ }^{+}\right) \mathrm{COO}^{-},{ }^{2}-\mathrm{CH}_{2} \mathrm{C}(\mathrm{O}) \mathrm{NH}_{2},{ }^{3}-\mathrm{CH}_{2} \mathrm{COO}^{-},{ }^{3}-\mathrm{CH}_{2}-$ $\mathrm{CH}_{2} \mathrm{NH}_{2},{ }^{4}$ and $-\mathrm{CH}_{3} .{ }^{5}$ Many of the porous materials reported in the literature have a common feature. ${ }^{1-4}$ Whereas the phosphonate anion contains a functional group that can act as a Lewis base, coordination to the metal atoms often occurs via this group in addition to coordination by the $-\mathrm{PO}_{3} \mathrm{H}_{n}^{-(2-n)}(n=0,1,2)$ group. This mode of coordination can lead to cross-linking of chains or lamellae to form 2D or 3D solids, or can occur entirely within discrete layers within a lamellar solid. In this respect, phosphonate anions containing carboxylate or carboxylic acid functional groups are ideally suited for the formation of porous materials, and a number of materials of this type, containing a variety of metals, have been reported in the literature. ${ }^{3,6-13}$

Of the phosphonocarboxylates reported, most contain carbon chains of two or more methylene units. A few, however, are based upon the phosphonoacetate anion, $\left[\mathrm{O}_{3} \mathrm{PCH}_{2} \mathrm{CO}_{2} \mathrm{H}\right]^{2-}$. Phosphonoacetic acid is a simple phosphonocarboxylic acid with only one methylene group separating the phosphonate and carboxylate groups. It can exist in any one of four forms: the fully protonated uncharged molecule, monoanionic (where one phosphonate oxygen is deprotonated), dianionic (where one

* To whom correspondence should be addressed. E-mail: gary.hix@ntu.ac.uk, demadis@chemistry.uoc.gr.

+ Nottingham Trent University.

* University of Crete. phosphonate and the carboxylate oxygens are deprotonated), and the fully deprotonated trianionic form. ${ }^{14}$ To date, $\mathrm{Zn},{ }^{3,9} \mathrm{Mn},{ }^{12,13}$ $\mathrm{Al},{ }^{15} \mathrm{Fe},{ }^{16} \mathrm{~Pb},{ }^{10,12}$ and $\mathrm{Cu}^{9}$ derivatives of phosphonoacetic acid have been reported in the literature, which variously contain all three possible forms of the phosphonoacetate anion.

$\mathrm{Fe}\left(\mathrm{O}_{3} \mathrm{PCH}_{2} \mathrm{CO}_{2}\right) \cdot \mathrm{H}_{2} \mathrm{O}^{16}$ and $\mathrm{Al}\left(\mathrm{O}_{3} \mathrm{PCH}_{2} \mathrm{CO}_{2}\right) \cdot 3 \mathrm{H}_{2} \mathrm{O}^{15}$ are both lamellar materials containing trivalent metal ions. In both cases the carboxylate group is coordinated to the metal atoms within the same layer, rather than cross-linking layers to form 3D materials. $\mathrm{Pb}_{6}\left(\mathrm{O}_{3} \mathrm{PCH}_{2} \mathrm{CO}_{2}\right)_{4}{ }^{12}$ and $\mathrm{Mn}_{3}\left(\mathrm{O}_{3} \mathrm{PCH}_{2} \mathrm{CO}_{2}\right)_{2}{ }^{12}$ exhibit 3D frameworks that are constructed from alternate inorganic metal oxide pillared by the organic groups. $\mathrm{Zn}_{3}\left(\mathrm{O}_{3} \mathrm{PCH}_{2} \mathrm{CO}_{2}\right)_{2} \cdot n \mathrm{H}_{2} \mathrm{O}^{3}$ has a framework structure that contains large channels $(10.0 \AA \times 6.8 \AA)$ in the [100] direction.

Both copper phosphonoacetates that have been reported in the literature are unusual. The first, $\mathrm{K}_{4}\left[\mathrm{Cu}\left(\mathrm{O}_{3} \mathrm{PCH}_{2^{-}}\right.\right.$ $\left.\left.\mathrm{CO}_{2}\right)_{2}\left(\mathrm{H}_{2} \mathrm{O}\right)\right] \cdot 4 \mathrm{H}_{2} \mathrm{O},{ }^{17}$ contains another metal cation in addition to copper and has an unusual and complex structure. It contains $\left[\mathrm{Cu}\left(\mathrm{O}_{3} \mathrm{PCH}_{2} \mathrm{CO}_{2}\right)_{2}\left(\mathrm{H}_{2} \mathrm{O}\right)\right]^{4-}$ complex anions in which $\mathrm{Cu}^{2+}$ is 5-coordinated in a distorted square based pyramidal environment. The phosphonoacetate anions coordinate to $\mathrm{Cu}^{2+}$ in a bidentate manner via one of the $\mathrm{O}_{3} \mathrm{P}^{-}$oxygen atoms and one of the carboxylate oxygens. The complex anions are cross-linked by $\mathrm{K}^{+}$coordinating to the remaining oxygen atoms.

The second has a composition of $\mathrm{Cu}\left(\mathrm{HO}_{3} \mathrm{PCH}_{2} \mathrm{CO}_{2} \mathrm{H}\right)_{2}$ $\left(\mathrm{H}_{2} \mathrm{O}\right)_{2}{ }^{18}$ and is one of an isostructural family of materials containing $\mathrm{Mg}, \mathrm{Mn}, \mathrm{Co}, \mathrm{Zn}$, and $\mathrm{Cu}$. All contain monoanions in which one of the phosphate $\mathrm{O}$ atoms is deprotonated. Each $\mathrm{Cu}^{2+}$ in the structure is in an octahedral environment that is coordinated by two phosphonate monoanions via the carbonyl and the deprotonated phosphonate oxygens. The two phosphonates thereby occupy the equatorial coordination positions, while the axial positions are occupied by water molecules. $\mathrm{The} \mathrm{Cu}-\mathrm{O}$ bond lengths show evidence of a Jahn-Teller effect in the $\mathrm{Cu}^{2+}$ environment. The layered structure of the material is then made 
Scheme 1. Molecular Formulae and Numbering of All Four $\mathrm{Cu}$-Phosphonocarboxylate Compounds

$\alpha-\mathrm{Cu}_{1.5}\left(\mathrm{O}_{3} \mathrm{PCH}_{2} \mathrm{CO}_{2}\right) \cdot \mathrm{H}_{2} \mathrm{O}$

$$
\beta-\mathrm{Cu}_{1.5}\left(\mathrm{O}_{3} \mathrm{PCH}_{2} \mathrm{CO}_{2}\right) \cdot \mathrm{H}_{2} \mathrm{O}
$$

$$
\mathrm{Cu}\left(\mathrm{HO}_{3} \mathrm{PCH}_{2} \mathrm{CO}_{2}\right) \cdot \mathrm{H}_{2} \mathrm{O}
$$

\section{$\left[\mathrm{Cu}\left(R, \mathrm{~S}-\mathrm{HO}_{3} \mathrm{PCH}(\mathrm{OH}) \mathrm{CO}_{2}\right)\left(\mathrm{H}_{2} \mathrm{O}\right)_{2}\right] \cdot \mathrm{H}_{2} \mathrm{O}(4)$}

up by the cross-linking of these complexes via hydrogen bonding between the phosphonate and carboxylate groups.

It has been noted that, by changing the reaction conditions, it is sometimes possible to synthesize a number of different materials from the same combination of metal salt and phosphonate anion. Examples include the families of aluminum phenylphosphonates and benzylphosphonates reported by $\mathrm{Ca}-$ beza $^{19}$ and Zakowsky, ${ }^{20}$ respectively, and the copper methylphosphonates, reported by Bujoli. ${ }^{5 a}$ One exception is that of $\mathrm{Ni}\left(\mathrm{O}_{3} \mathrm{PCH}_{2} \mathrm{CONH}_{2}\right) \cdot \mathrm{H}_{2} \mathrm{O}$, which is synthesized hydrothermally using nickel acetate and diethyl cyanomethylphosphonate and yields a small quantity of crystals of a porous material among a much larger quantity of layered material in a polycrystalline form. ${ }^{21}$ Attempts to synthesize the porous material as a single phase were unsuccessful. It is quite common that different products are formed from a particular set of reagents have the different compositions and are not polymorphs of one another. More often, the materials will contain different M:P ratios, arising from charge variations on the phosphonate anion backbone, which, in turn, are dependent on reaction mixture $\mathrm{pH}$. Other variations include the number of water molecules (either metal-coordinated or in the lattice) in the structure. This is often a result of differences in the coordination number, environment of the metal atoms, and hydrogen bonding schemes.

In this paper, we report the results of our investigations into the copper phosphonoacetate family of materials. Hydrothermal reactions between copper acetate and diethyl phosphonoacetic acid or phosphonoacetic acid have been carried out at different temperatures and reagent ratios. The syntheses have resulted in the formation of three new materials, two of which are polymorphs. In an attempt to further rationalize how the nature of the organic group of the phosphonic acid affects the structure of the products, a $\mathrm{Cu}$-HPAA material has also been synthesized. In the resulting material, the presence of an -OH group on the carbon adjacent to the phosphonate group has a profound effect upon the structure, yielding a one-dimensional material. The molecular formulas and numbering of all four compounds are given in Scheme 1.

\section{Experimental Section}

Syntheses. Initial Attempts to Obtain Pure 1, 2, and 3. The title materials are formed by a hydrothermal reaction between copper acetate tetrahydrate (Sigma-Aldrich, UK) and diethyl phosphonoacetic acid (DEPAA) (Sigma-Aldrich, UK). An initial synthesis followed a standard method in which equimolar quantities of copper acetate and the DEPAA $(3.7 \mathrm{mmol})$ are mixed with $10 \mathrm{~mL}$ distilled water and placed in a Teflon lined stainless steel autoclave with a $23 \mathrm{~mL}$ capacity. The $\mathrm{pH}$ of the reaction mixture is 4.5 . The weak acidity of the reaction solution is sufficient to enable an acid hydrolysis of the diethyl phosphonate ester, DEPAA, making the free phosphonic acid available for reaction with the copper ions in solution. At this $\mathrm{pH}$, the free phosphonic acid readily deprotonates, thus releasing carboxyphosphonate anions that react with $\mathrm{Cu}^{2+}$. The hydrolysis reaction is slow compared to the complexation of $\mathrm{Cu}^{2+}$; hence, the reaction proceeds slowly, allowing crystals to grow. ${ }^{22}$ The autoclave was then heated at $160{ }^{\circ} \mathrm{C}$ for two days. After this time, the product was recovered by filtration, washed in distilled water and allowed to dry in air. Inspection of the sample clearly indicated the presence of more than one phase; blue plate-like crystals were mixed with green block-shaped crystals. The blue sample is henceforth referred to as the $\alpha$-phase, and the green material is denoted the $\beta$-phase. Samples of both were selected manually for crystallographic investigation.

In an attempt to produce a single phase of either of the materials, an additional synthetic procedure was carried out using a $\mathrm{Cu}$ : Phosphonate ratio of $3: 2$, thereby taking account of the fact that the phosphonoacetate anion could be present in the product as either a dior trianion. The products were, however, observed to be the same mixture of blue and green crystals.

Further attempts to access a different part of the phase diagram involved carrying out the reaction at temperatures higher and lower than that of the original experiment $\left(180\right.$ and $\left.140{ }^{\circ} \mathrm{C}\right)$. The reaction carried out at the higher temperature gave rise to the green product only, while the lower temperature synthesis yielded only the blue material.

Synthesis of $\mathrm{Cu}_{1.5}\left(\mathrm{O}_{3} \mathrm{PCH}_{2} \mathrm{CO}_{2}\right) \cdot \mathrm{H}_{2} \mathrm{O}$ (1). The $\mathrm{pH}$ of the initial mixture was 4.5 and was not further adjusted. Treatment of the 1:1 $\mathrm{Cu}: \mathrm{P}$ reaction mixture at $140{ }^{\circ} \mathrm{C}$ resulted in the formation of the blue material (hereafter referred to as the $\alpha$-phase) as a single phase product. Another single crystal measurement was carried out on this material, confirming it to be identical to the blue phase obtained at $160{ }^{\circ} \mathrm{C}$. The single phase nature of this material was confirmed by comparison of an observed powder X-ray diffraction pattern with one generated from the single crystal data. The same result was obtained for a synthesis carried out at $120^{\circ} \mathrm{C}$. Isolation of the material as a single phase allowed $\mathrm{CHN}$ analyses to be carried out. These results confirmed the composition determined during the single crystal analysis. Calculated: $9.59 \%$ C, $1.61 \% \mathrm{H}$. Experimental: $9.51 \% \mathrm{C}, 1.80 \% \mathrm{H}$.

Synthesis of $\mathrm{Cu}_{1.5}\left(\mathrm{O}_{3} \mathrm{PCH}_{2} \mathrm{CO}_{2}\right) \cdot \mathrm{H}_{2} \mathrm{O}$ (2). The $\mathrm{pH}$ of the starting mixture was 4.5. Treatment of the same 1:1 reaction mixture at 180 ${ }^{\circ} \mathrm{C}$ results in the formation, as a single phase product, of the green phase obtained at $160{ }^{\circ} \mathrm{C}$. Again, this was confirmed by additional single crystal analysis and comparison with powder diffraction patterns. $\mathrm{CHN}$ analysis confirms the composition of $\mathbf{2}$ phase to be the same as that of the $\mathbf{1}$ and corresponds to the stoichiometry obtained from the single crystal analysis. Calculated: $9.59 \%$ C, $1.61 \%$ H. Experimental: $9.45 \%$ $\mathrm{C}, 1.33 \% \mathrm{H}$.

Synthesis of $\mathrm{Cu}\left(\mathrm{HO}_{3} \mathrm{PCH}_{2} \mathrm{CO}_{2}\right) \cdot \mathrm{H}_{2} \mathrm{O}$ (3). Treatment of a reaction mixture with an initial $\mathrm{pH}$ of 4.5 and a $\mathrm{Cu}: \mathrm{P}$ ratio of $2: 3$ (taking into account the stoïchiometry of the previously obtained products) at 160 ${ }^{\circ} \mathrm{C}$ again gave rise to a mixture of products. In this case, however, the products contained $\mathrm{Cu}_{1.5}\left(\mathrm{O}_{3} \mathrm{PCH}_{2} \mathrm{CO}_{2}\right) \cdot \mathrm{H}_{2} \mathrm{O}(\mathbf{1}), \mathrm{Cu}_{1.5}\left(\mathrm{O}_{3} \mathrm{PCH}_{2^{-}}\right.$ $\left.\mathrm{CO}_{2}\right) \cdot \mathrm{H}_{2} \mathrm{O}(2)$ and bright blue, block-shaped crystals. Single crystal analysis of the new product (vide infra) showed the product to have a composition of $\mathrm{Cu}\left(\mathrm{HO}_{3} \mathrm{PCH}_{2} \mathrm{CO}_{2}\right) \cdot \mathrm{H}_{2} \mathrm{O}(3)$. When the reaction temperature was raised to $180{ }^{\circ} \mathrm{C}$, this material was obtained as a single phase, allowing a $\mathrm{CHN}$ analysis to be carried out, again confirming the composition determined from the single crystal analysis. Calculated: $10.94 \%$ C, $2.30 \%$ H. Experimental: $10.77 \%$ C, $2.22 \% \mathrm{H}$.

Synthesis of $\left[\mathrm{Cu}\left(\mathrm{HO}_{3} \mathrm{PCH}(\mathrm{OH}) \mathrm{CO}_{2}\right)\left(\mathrm{H}_{2} \mathrm{O}\right)_{2}\right] \cdot \mathrm{H}_{2} \mathrm{O}(4)$. Synthesis of 4 was carried out by placing HPAA (Biolab, U.K., $0.2 \mathrm{~mL}$ of a $50 \%$ w/w solution, $0.874 \mathrm{mmol}$ ) in $25 \mathrm{~mL} \mathrm{H}_{2} \mathrm{O}$ and then slowly adding solid $\mathrm{CuCl}_{2} \cdot 2 \mathrm{H}_{2} \mathrm{O}$ (Aldrich, USA, $0.149 \mathrm{~g}, 0.874 \mathrm{mmol}$ 1:1 molar ratio). Solution $\mathrm{pH}$ was adjusted to 2 with a $\mathrm{NaOH}$ stock solution. Crystal growth was allowed to proceed over 4 days. The light blue crystals were isolated by filtration, washed with deionized water and air-dried. This synthesis yielded a single phase material, as evidenced by XRD. Material 4 looses water rather easily. This is clearly seen when single crystals are exposed to air. Yields vary from 40 to $50 \%$ depending on crystallization time. Numerous CHN analyses were carried out on $\mathbf{4}$, with mixed success. Therefore, $\mathrm{CHN}$ analysis was carried out on an oven-dried (at $60{ }^{\circ} \mathrm{C}$ ) sample (Calculated: 9.46\% C, $2.76 \% \mathrm{H}$. Experimental: $9.87 \% \mathrm{C}, 2.68 \% \mathrm{H}$ ). These results are consistent with the formulation $\left[\mathrm{Cu}\left(R, S-\mathrm{HO}_{3} \mathrm{PCH}(\mathrm{OH}) \mathrm{CO}_{2}\right)\left(\mathrm{H}_{2} \mathrm{O}\right)_{2}\right]$, a solid that is essentially $\mathbf{4}$ after loss of one water of crystallization.

Single Crystal Determinations. Data on 1, 2, and $\mathbf{3}$ were collected by the EPSRC X-ray Crystallography Service at the University of Southampton. Data were collected on a Nonius Kappa CCD areadetector diffractometer at the window of a rotating anode FR591 generator (Mo $\mathrm{K} \alpha$ radiation, $\lambda=0.71073 \AA$ ) and controlled by the 


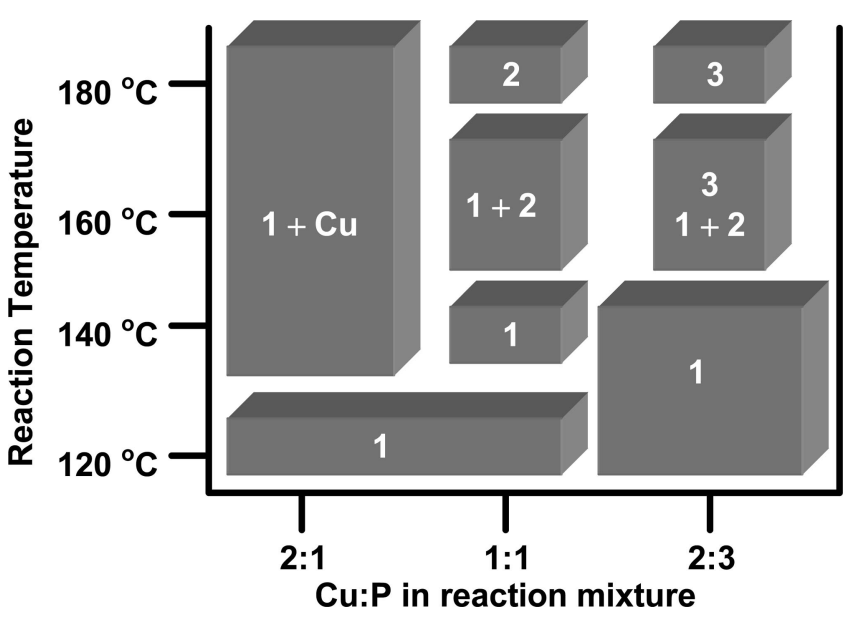

Figure 1. Products formed from reactions between copper acetate and diethylphosphonoacetic acid, under hydrothermal conditions at different temperatures and with varying reactant ratios. Numbers in the Figure refer to numbered compounds listed in Scheme 1.

Collect software package. ${ }^{23}$ Collected images were processed using Denzo. ${ }^{24}$ Data were corrected for absorption using the empirical method employed in Sortav. ${ }^{25}$ The structures were solved using direct methods in SHELXS-97 $7^{26,27}$ (employed within the WinGX suite of programs). ${ }^{28}$ $\mathrm{X}$-ray diffraction data on $\mathbf{4}$ were collected on a SMART 1K CCD diffractometer at $298(2) \mathrm{K}$ with $\mathrm{Mo} \mathrm{K \alpha}(\lambda=0.71073 \AA)$.

All structures were subsequently refined by full-matrix least-squares refinement on $\mathrm{F}^{2}$ (SHELXL97). ${ }^{26,27}$ Non-hydrogen atoms were refined anisotropically. For $\mathbf{2}$ anisotropic refinement of $\mathrm{C} 2$ yielded nonpositive definites in the thermal parameter. These were handled by tying the thermal parameters of the two $\mathrm{C}$ atoms of the anion together using the SIMU command in SHELXL.

Hydrogen atoms were either located in the difference Fourier map or placed geometrically. Subsequent refinement of the thermal parameters was carried out isotropically in all cases. CCDC Reference numbers: $\alpha-\mathrm{Cu}_{1.5}\left(\mathrm{O}_{3} \mathrm{PCH}_{2} \mathrm{CO}_{2}\right) \cdot \mathrm{H}_{2} \mathrm{O}$ (1) $\mathrm{CCDC}-242268, \beta-\mathrm{Cu}_{1.5^{-}}$ $\left(\mathrm{O}_{3} \mathrm{PCH}_{2} \mathrm{CO}_{2}\right) \cdot \mathrm{H}_{2} \mathrm{O}(\mathbf{2}) \mathrm{CCDC}-242269, \mathrm{Cu}\left(\mathrm{HO}_{3} \mathrm{PCH}_{2} \mathrm{CO}_{2}\right) \cdot \mathrm{H}_{2} \mathrm{O}(\mathbf{3})$ $\mathrm{CCDC}-242270$ and $\left[\mathrm{Cu}\left(\mathrm{HO}_{3} \mathrm{PCH}(\mathrm{OH}) \mathrm{CO}_{2}\right)\left(\mathrm{H}_{2} \mathrm{O}\right)_{2}\right] \cdot \mathrm{H}_{2} \mathrm{O}$ (4) CCDC641330. In all Figures, the following color codes are used: $\mathrm{Cu}$ blue, $\mathrm{P}$ orange, $\mathrm{O}$ red, $\mathrm{C}$ gray, $\mathrm{H}$ white.

Sample Characterization. Infrared spectra of all samples were recorded using a Nicolet 5DXC spectrometer. Samples were mounted as self-supporting $\mathrm{KBr}$ disks, which contained $\mathrm{ca} .1 \%$ sample by mass. CHN contents were determined using a Carlos Elba 1011 analyzer. Thermogravimetric analyses were carried out using a TA50 thermogravimetric analyzer, in an air atmosphere, from room temperature to $800{ }^{\circ} \mathrm{C}$, with a heating rate of $10^{\circ} \mathrm{C} /$ minute.

\section{Results}

Synthetic Studies. The hydrothermal synthetic procedure was carried out using different $\mathrm{Cu}: \mathrm{P}$ ratios and at different temperatures. Figure 1 shows which products are obtained from each of the $\mathrm{Cu}: \mathrm{P}$ ratios used at the different reaction temperatures. The initial experiment carried out in the investigation of this system was carried out using a 1:1 mol ratio of copper acetate to DPAA (or $\mathrm{Cu}: \mathrm{P}$ ratio) at $160{ }^{\circ} \mathrm{C}$. The products appeared to consist of three phases: large dark-green block crystals, large bright-blue plates, and small turquoise plates. Crystals were separated by hand and investigated by single crystal methods, which showed the bright-blue and turquoise materials to be the same phase. Hence, the products of this reaction are biphasic, with both phases having a composition of $\mathrm{Cu}_{1.5}\left(\mathrm{O}_{3} \mathrm{PCH}_{2-}\right.$ $\left.\mathrm{CO}_{2}\right) \cdot \mathrm{H}_{2} \mathrm{O}$, but with different structures (vide infra).

Treatment of the $1: 1 \mathrm{Cu}: \mathrm{P}$ reaction mixture at $140{ }^{\circ} \mathrm{C}$ resulted in the formation of the blue material (hereafter referred to as the $\alpha$-phase) as a single phase product. Another single crystal measurement was carried out on this material, confirming it to be identical to the blue phase obtained at $160{ }^{\circ} \mathrm{C}$. The single phase nature of this material was confirmed by comparison of an observed powder X-ray diffraction pattern with one generated from the single crystal data. The same result was obtained for a synthesis carried out at $120{ }^{\circ} \mathrm{C}$. Isolation of the material as a single phase allowed $\mathrm{CHN}$ analyses to be carried out. These results confirmed the elemental composition determined during the single crystal analysis.

Treatment of the same $1: 1$ reaction mixture at $180{ }^{\circ} \mathrm{C}$ results in the formation, as a single phase product, of the green phase obtained at $160{ }^{\circ} \mathrm{C}$. Again, this was confirmed by additional single crystal analysis and comparison with powder diffraction patterns. $\mathrm{CHN}$ analysis confirms the composition of the $\beta$ phase to be the same as that of the $\alpha$-phase and corresponds to the stoichiometry obtained from the single crystal analysis.

Treatment of a reaction mixture with a $\mathrm{Cu}: \mathrm{P}$ ratio of $2: 3$ (taking into account the stoichiometry of the previously obtained products) at $160{ }^{\circ} \mathrm{C}$ again gave rise to a mixture of products. In this case, however, the products contained $\mathrm{Cu}_{1.5}\left(\mathrm{O}_{3} \mathrm{PCH}_{2}-\right.$ $\left.\mathrm{CO}_{2}\right) \cdot \mathrm{H}_{2} \mathrm{O}(1), \mathrm{Cu}_{1.5}\left(\mathrm{O}_{3} \mathrm{PCH}_{2} \mathrm{CO}_{2}\right) \cdot \mathrm{H}_{2} \mathrm{O}$ (2), and bright-blue, block-shaped crystals. Single crystal analysis of the new product (vide infra) showed the product to have a composition of $\mathrm{Cu}\left(\mathrm{HO}_{3} \mathrm{PCH}_{2} \mathrm{CO}_{2}\right) \cdot \mathrm{H}_{2} \mathrm{O}(3)$. When the reaction temperature was raised to $180{ }^{\circ} \mathrm{C}$, this material was obtained as a single phase, allowing a $\mathrm{CHN}$ analysis to be carried out, again confirming the composition determined from the single crystal analysis. Using the same 2:3 $\mathrm{Cu}: \mathrm{P}$ reactant ratio at a reaction temperature of $140{ }^{\circ} \mathrm{C}$ or below results in the formation of $\mathbf{1}$ only.

A further change in the relative amounts of the starting reagents such that the $\mathrm{Cu}: \mathrm{P}$ ratio was $2: 1$ did not yield any new materials. At temperatures of $140{ }^{\circ} \mathrm{C}$ and above, the hydrothermal reaction gave rise to a mixture of copper metal and $\mathbf{1}$. The quantity of copper metal obtained increased as the reaction temperature was raised.

Reaction of hydrated copper chloride and HPAA at low $\mathrm{pH}$ and room temperature yielded $\left[\mathrm{Cu}\left(R, S-\mathrm{HO}_{3} \mathrm{PCH}(\mathrm{OH}) \mathrm{CO}_{2}\right)\right.$ $\left.\left(\mathrm{H}_{2} \mathrm{O}\right)_{2}\right] \cdot \mathrm{H}_{2} \mathrm{O}(\mathbf{4})$ as a single phase product. Phase purity was demonstrated by powder XRD. Material 4 loses water rather easily. This is clearly seen when single crystals are exposed to air for a prolonged period of time. They become opaque and lose their sharp edges, but they retain their bulk crystallinity. ${ }^{29}$ Yields vary from 40 to $50 \%$ depending on crystallization time. Numerous elemental analyses were carried out on $\mathbf{4}$, with mixed success. Therefore, CHN analysis was carried out on an ovendried sample and the results are consistent with the formulation $\left[\mathrm{Cu}\left(R, S-\mathrm{HO}_{3} \mathrm{PCH}(\mathrm{OH}) \mathrm{CO}_{2}\right)\left(\mathrm{H}_{2} \mathrm{O}\right)_{2}\right]$, a solid that is essentially $\mathbf{4}$ after loss of one water of crystallization. The synthesis of $\mathbf{4}$ is simple, high-yield, and affords no byproduct. It is based on a slow approach of a $\mathrm{pH}$ region where electroneutrality (charge of the metal ion = charge of the ligand) is reached and has yielded a plethora of metal-organic frameworks. ${ }^{30}$ Synthesis of 4 was also performed under solvothermal conditions $\left(\sim 120^{\circ} \mathrm{C}\right)$ yielding the same material as the ambient temperature synthesis.

Crystal Structures. Structure of $\mathrm{Cu}_{1.5}\left(\mathrm{O}_{3} \mathrm{PCH}_{2} \mathrm{CO}_{2}\right) \cdot \mathrm{H}_{2} \mathrm{O}$ (1). Single crystal diffraction studies of the blue plate shaped crystals of $\mathrm{Cu}_{1.5}\left(\mathrm{O}_{3} \mathrm{PCH}_{2} \mathrm{CO}_{2}\right) \cdot \mathrm{H}_{2} \mathrm{O}$ revealed that the material crystallizes in the triclinic space group $P \overline{1}$ (No. 2). A summary of the crystallographic data is given in Table 1 with selected bond lengths and angles in Table 2.

The asymmetric unit contains 11 non-hydrogen atoms (Figure 2, upper). The ligand coordinates to six $\mathrm{Cu}^{2+}$ ions (Figure 2, lower). The material has a lamellar structure with the layers stacked in the b direction. The layers contain two crystallo- 
Table 1. Crystallographic Data for $\mathrm{Cu}_{1.5}\left(\mathrm{O}_{3} \mathrm{PCH}_{2} \mathrm{CO}_{2}\right) \cdot \mathrm{H}_{2} \mathrm{O}(1), \mathrm{Cu}_{1.5}\left(\mathrm{O}_{3} \mathrm{PCH}_{2} \mathrm{CO}_{2}\right) \cdot \mathrm{H}_{2} \mathrm{O}(2), \mathrm{Cu}\left(\mathrm{HO}_{3} \mathrm{PCH}_{2} \mathrm{CO}_{2}\right) \cdot \mathrm{H}_{2} \mathrm{O}(3)$, and $\left[\mathrm{Cu}\left(\mathrm{R}, \mathrm{S}-\mathrm{HO}_{3} \mathrm{PCH}(\mathrm{OH}) \mathrm{CO}_{2}\right)\left(\mathrm{H}_{2} \mathrm{O}\right)_{2}\right] \cdot \mathrm{H}_{2} \mathrm{O}(4)$

\begin{tabular}{|c|c|c|c|c|}
\hline material & (1) & (2) & (3) & (4) \\
\hline Empirical formula & $\mathrm{C}_{2} \mathrm{H}_{4} \mathrm{Cu}_{1.5} \mathrm{O}_{6} \mathrm{P}$ & $\mathrm{C}_{2} \mathrm{H}_{4} \mathrm{Cu}_{1.5} \mathrm{O}_{6} \mathrm{P}$ & $\mathrm{C}_{2} \mathrm{H}_{5} \mathrm{CuO}_{6} \mathrm{P}$ & $\mathrm{C}_{2} \mathrm{H}_{9} \mathrm{CuO}_{9} \mathrm{P}$ \\
\hline F.W. & 250.33 & 250.33 & 219.57 & 271.60 \\
\hline Space group & $P \overline{1}($ No. 2$)$ & $P 2_{1} / c($ No. 14$)$ & $P \overline{1}($ No. 2$)$ & Pbca (No. 61) \\
\hline$a(\AA)$ & $4.6512(5)$ & $8.2713(2)$ & $6.0979(2)$ & $8.623(3)$ \\
\hline$b(\AA)$ & $7.9368(8)$ & $7.5587(2)$ & $6.3860(3)$ & $9.893(3)$ \\
\hline$c(\AA)$ & $8.0583(8)$ & $9.0004(2)$ & $8.0968(3)$ & $18.924(5)$ \\
\hline$\alpha(\operatorname{deg})$ & $108.3430(10)$ & 90.00 & $73.766(2)$ & 90.00 \\
\hline$\beta$ (deg) & $100.3880(10)$ & $90.195(2)$ & $69.441(2)$ & 90.00 \\
\hline$\gamma(\mathrm{deg})$ & $92.2010(10)$ & 90.00 & $80.937(2)$ & 90.00 \\
\hline$V(\AA)$ & $276.29(5)$ & $562.70(2)$ & $282.829(19)$ & $1614.3(8)$ \\
\hline $\mathrm{Z}$ & 2 & 4 & 2 & 8 \\
\hline Temp. (K) & 120 & 120 & 120 & 298 \\
\hline$\lambda(\AA)$ & 0.71073 & 0.71073 & 0.71073 & 0.71073 \\
\hline$\rho_{\text {calcd }}\left(\mathrm{g} \cdot \mathrm{cm}^{-3}\right)$ & 3.009 & 2.955 & 2.578 & 2.235 \\
\hline$\mu\left(\mathrm{mm}^{-1}\right)$ & 6.081 & 5.972 & 4.109 & 2.929 \\
\hline Meas. Refl./Unique Refl. & $3830 / 1229$ & $5573 / 1295$ & $4840 / 1293$ & $11181 / 1962$ \\
\hline$R_{\text {int }}$ & 0.0936 & 0.0582 & 0.0549 & 0.0300 \\
\hline Final $R$ index $[I>2 \sigma(I)]$ & 0.0420 & 0.0277 & 0.0323 & 0.0315 \\
\hline Final wR2 index $[I>2 \sigma(I)]$ & 0.1036 & 0.0703 & 0.0866 & 0.0646 \\
\hline$R\left(F_{0}\right)_{\text {all }}$ & 0.0519 & 0.0327 & 0.0336 & 0.0413 \\
\hline $\mathrm{w} R\left(F_{0}^{2}\right)_{\text {all }}$ & 0.1130 & 0.0821 & 0.0879 & 0.0673 \\
\hline GoF & 1.025 & 1.135 & 1.105 & 1.087 \\
\hline
\end{tabular}

Table 2. Bond Lengths [̊̊] and Angles [deg] for $\mathrm{Cu}_{1.5}\left(\mathrm{HO}_{3} \mathrm{PCH}_{2} \mathrm{CO}_{2}\right) \cdot \mathrm{H}_{2} \mathrm{O}(1)$

\begin{tabular}{llll}
\hline \multicolumn{4}{c}{ Bonds } \\
\hline $\mathrm{Cu}(1)-\mathrm{O}(1)^{a}$ & $1.940(3)$ & $\mathrm{P}(1)-\mathrm{O}(2)$ & $1.516(3)$ \\
$\mathrm{Cu}(1)-\mathrm{O}(1)^{b}$ & $1.940(3)$ & $\mathrm{P}(1)-\mathrm{O}(3)$ & $1.552(3)$ \\
$\mathrm{Cu}(1)-\mathrm{O}(2)^{c}$ & $1.956(3)$ & $\mathrm{P}(1)-\mathrm{C}(1)$ & $1.805(4)$ \\
$\mathrm{Cu}(1)-\mathrm{O}(2)$ & $1.956(3)$ & $\mathrm{O}(3)-\mathrm{Cu}(2)^{f}$ & $1.961(3)$ \\
$\mathrm{Cu}(2)-\mathrm{O}(6)^{d}$ & $1.909(3)$ & $\mathrm{O}(3)-\mathrm{Cu}(2)^{d}$ & $1.972(3)$ \\
$\mathrm{Cu}(2)-\mathrm{O}(3)^{a}$ & $1.961(3)$ & $\mathrm{O}(1)-\mathrm{Cu}(1)^{f}$ & $1.940(3)$ \\
$\mathrm{Cu}(2)-\mathrm{O}(3)^{d}$ & $1.972(3)$ & $\mathrm{C}(1)-\mathrm{C}(2)$ & $1.510(6)$ \\
$\mathrm{Cu}(2)-\mathrm{O}(5)$ & $2.004(3)$ & $\mathrm{O}(4)-\mathrm{C}(2)$ & $1.244(6)$ \\
$\mathrm{Cu}(2)-\mathrm{O}(2)$ & $2.284(3)$ & $\mathrm{C}(2)-\mathrm{O}(6)$ & $1.269(5)$ \\
$\mathrm{Cu}(2)-\mathrm{Cu}(2)^{e}$ & $3.012(1)$ & $\mathrm{O}(6)-\mathrm{Cu}(2)^{d}$ & $1.909(3)$ \\
$\mathrm{P}(1)-\mathrm{O}(1)$ & $1.503(3)$ & & \\
\hline
\end{tabular}

\begin{tabular}{lclr}
\hline \multicolumn{5}{c}{ Angles } \\
\hline $\mathrm{O}(1)-\mathrm{Cu}(1)-\mathrm{O}(1)^{b}$ & 180 & $\mathrm{O}(6)^{d}-\mathrm{Cu}(2)-\mathrm{O}(5)$ & $92.90(14)$ \\
$\mathrm{O}(1)-\mathrm{Cu}(1)-\mathrm{O}(2)^{c}$ & $89.62(13)$ & $\mathrm{O}(3)-\mathrm{Cu}(2)-\mathrm{O}(5)$ & $91.30(14)$ \\
$\mathrm{O}(1)-\mathrm{Cu}(1)-\mathrm{O}(2)^{c}$ & $90.38(13)$ & $\mathrm{O}(3)^{d}-\mathrm{Cu}(2)-\mathrm{O}(5)$ & $166.72(14)$ \\
$\mathrm{O}(1)-\mathrm{Cu}(1)-\mathrm{O}(2)$ & $90.38(13)$ & $\mathrm{O}(6)^{d}-\mathrm{Cu}(2)-\mathrm{O}(2)$ & $86.17(12)$ \\
$\mathrm{O}(1)^{b}-\mathrm{Cu}(1)-\mathrm{O}(2)$ & $89.62(13)$ & $\mathrm{O}(3)^{a}-\mathrm{Cu}(2)-\mathrm{O}(2)$ & $90.03(12)$ \\
$\mathrm{O}(2)^{c}-\mathrm{Cu}(1)-\mathrm{O}(2)$ & 180 & $\mathrm{O}(3)^{d}-\mathrm{Cu}(2)-\mathrm{O}(2)$ & $103.69(12)$ \\
$\mathrm{O}(6)^{d}-\mathrm{Cu}(2)-\mathrm{O}(3)^{a}$ & $174.13(12)$ & $\mathrm{O}(5)-\mathrm{Cu}(2)-\mathrm{O}(2)$ & $86.24(12)$ \\
$\mathrm{O}(6)^{d}-\mathrm{Cu}(2)-\mathrm{O}(3)^{d}$ & $96.49(13)$ & $\mathrm{C}(2)-\mathrm{O}(6)-\mathrm{Cu}(2)^{d}$ & $125.4(3)$ \\
$\mathrm{O}(3)^{a}-\mathrm{Cu}(2)-\mathrm{O}(3)^{d}$ & $80.06(14)$ & &
\end{tabular}

${ }^{a}$ Symmetry transformation used to generate equivalent atoms: $x+1$, $y, z .{ }^{b}$ Symmetry transformation used to generate equivalent atoms: $-x$, $-y+1,-z+1 .^{c}$ Symmetry transformation used to generate equivalent atoms: $-x+1,-y+1,-z+1{ }^{d}$ Symmetry transformation used to generate equivalent atoms: $-x,-y+1,-z .{ }^{e}$ Symmetry transformation used to generate equivalent atoms: $-x+1,-y+1,-z .{ }^{f}$ Symmetry transformation used to generate equivalent atoms: $x-1, y, z$.

graphically independent $\mathrm{Cu}$ atoms in distorted octahedral $\mathrm{CuO}_{6}$ environments; $\mathrm{Cu}(1)$ lies on an inversion center. Both of the $\mathrm{Cu}$ environments are Jahn-Teller distorted with two long axial $\mathrm{Cu}-\mathrm{O}$ bonds and four short $\mathrm{Cu}-\mathrm{O}$ equatorial bonds (Table 2). The $\mathrm{P}$ atom has a tetrahedral $\mathrm{CPO}_{3}$ environment, with $\mathrm{P}-\mathrm{O}$ bond lengths in the region $1.50-1.55 \AA$ and a $\mathrm{P}-\mathrm{C}$ bond length of $1.805 \AA$.

The $\mathrm{CuO}_{6}$ octahedra are joined via edge sharing to form stepped chains parallel with the $c$ axis (Figure 3). Viewed from this direction, the layers contain distinct groups of three octahedra, with the step occurring in the chain as these groups of three are connected (Figure 3). The central $\mathrm{CuO}_{6}$ joins with the two outer ones via edges trans to one another; the join

between the larger subunits giving rise to the step occurs via sharing of edges cis to one another.

The chains are cross-linked by the $-\mathrm{PO}_{3}$ groups (Figure 3), which have $(122)^{31}$ connectivity. The linking is such that the $\mathrm{O}$ atoms that are shared between two $\mathrm{Cu}$ atoms are in different chains. The cross-linking is further reinforced by the oxygen atoms of the carboxylate group that coordinate to $\mathrm{Cu}(2)$ atoms in different chains. The lengths of the $\mathrm{C}-\mathrm{O}$ bonds are similar; $\mathrm{C}(2)-\mathrm{O}(4) 1.244 \AA, \mathrm{C}(2)-\mathrm{O}(6) 1.268 \AA$.

Bonding of the carboxylate group to a metal atom which is in the same layer as those coordinated by the $-\mathrm{PO}_{3}$ oxygen atoms is unusual and has previously been observed only once before, to the best of our knowledge, in $\mathrm{Al}\left(\mathrm{O}_{3} \mathrm{PCH}_{2} \mathrm{CO}_{2}\right) \cdot 3 \mathrm{H}_{2} \mathrm{O} .{ }^{15}$ It is
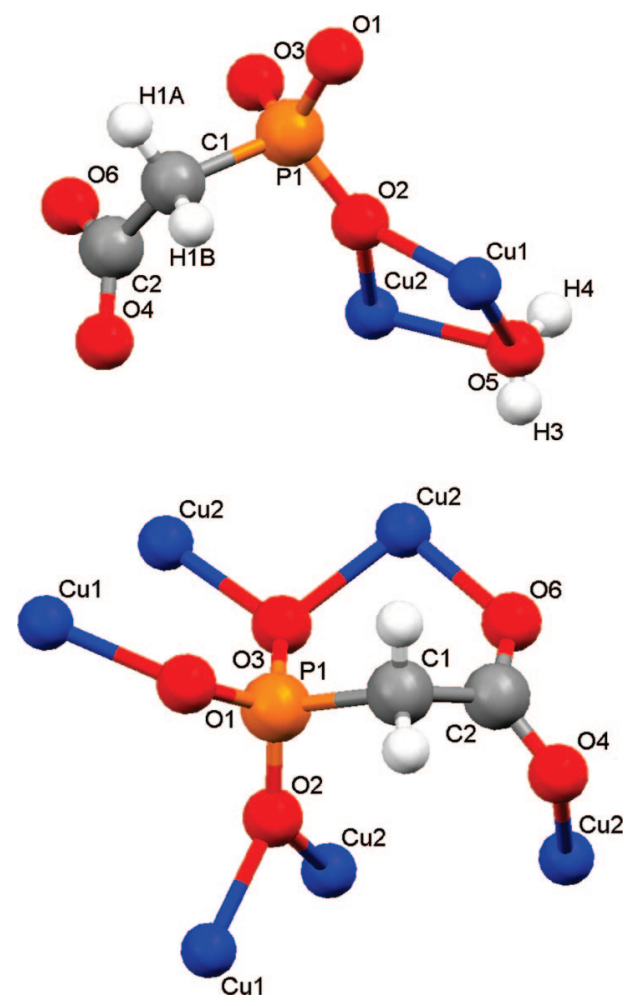

Figure 2. Asymmetric unit of $\mathrm{Cu}_{1.5}\left(\mathrm{O}_{3} \mathrm{PCH}_{2} \mathrm{CO}_{2}\right) \cdot \mathrm{H}_{2} \mathrm{O}(\mathbf{1}$, upper $)$ and the coordination mode of phosphonoacetate (lower). 


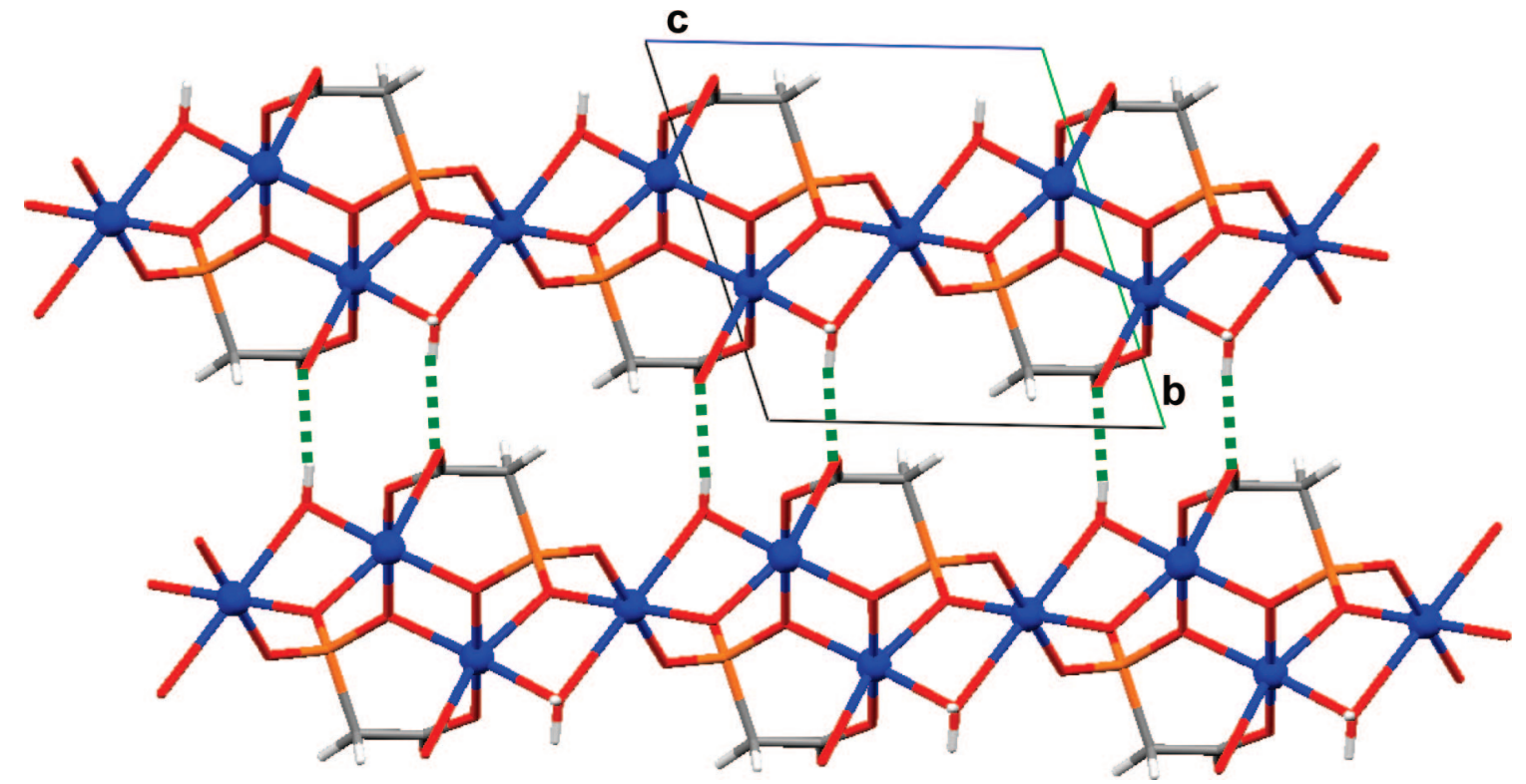

Figure 3. Adjacent layers in the structure of $\alpha-\mathrm{Cu}_{1.5}\left(\mathrm{O}_{3} \mathrm{PCH}_{2} \mathrm{CO}_{2}\right) \cdot \mathrm{H}_{2} \mathrm{O}(\mathbf{1})$ viewed along the $a$ axis. Hydrogen bonds that hold the layers together are shown in dotted lines.

Table 3. Bond Lengths $[\AA]$ and Angles $[\mathrm{deg}]$ for $\mathrm{Cu}_{1.5}\left(\mathrm{HO}_{3} \mathrm{PCH}_{2} \mathrm{CO}_{2}\right) \cdot \mathrm{H}_{2} \mathrm{O}$ (2)

\begin{tabular}{|c|c|c|c|}
\hline \multicolumn{4}{|c|}{ Bonds } \\
\hline $\mathrm{Cu}(1)-\mathrm{O}(2)$ & $1.944(2)$ & $\mathrm{P}(1)-\mathrm{O}(3)$ & $1.514(2)$ \\
\hline $\mathrm{Cu}(1)-\mathrm{O}(2)^{a}$ & $1.944(2)$ & $\mathrm{P}(1)-\mathrm{O}(1)$ & $1.530(2)$ \\
\hline $\mathrm{Cu}(1)-\mathrm{O}(4)^{a}$ & $1.951(2)$ & $\mathrm{P}(1)-\mathrm{O}(2)$ & $1.539(2)$ \\
\hline $\mathrm{Cu}(1)-\mathrm{O}(4)$ & $1.951(2)$ & $\mathrm{O}(1)-\mathrm{Cu}(2)^{c}$ & $1.924(2)$ \\
\hline $\mathrm{Cu}(2)-\mathrm{O}(3)^{b}$ & $1.904(2)$ & $\mathrm{O}(3)-\mathrm{Cu}(2)^{d}$ & $1.905(2)$ \\
\hline $\mathrm{Cu}(2)-\mathrm{O}(1)^{c}$ & $1.924(2)$ & $\mathrm{O}(4)-\mathrm{C}(2)$ & $1.305(3)$ \\
\hline $\mathrm{Cu}(2)-\mathrm{O}(5)$ & $1.955(2)$ & $\mathrm{O}(4)-\mathrm{Cu}(2)^{a}$ & $2.058(2)$ \\
\hline $\mathrm{Cu}(2)-\mathrm{O}(4)^{a}$ & $2.058(2)$ & $\mathrm{O}(6)-\mathrm{C}(2)$ & $1.231(4)$ \\
\hline $\mathrm{Cu}(2)-\mathrm{O}(2)$ & $2.348(2)$ & $C(2)-C(1)$ & $1.495(4)$ \\
\hline \multicolumn{4}{|c|}{ Angles } \\
\hline $\mathrm{O}(2)-\mathrm{Cu}(1)-\mathrm{O}(2)^{a}$ & 180 & $\mathrm{O}(1)^{c}-\mathrm{Cu}(2)-\mathrm{O}(5)$ & $89.78(8)$ \\
\hline $\mathrm{O}(2)-\mathrm{Cu}(1)-\mathrm{O}(4)^{a}$ & $81.99(9)$ & $\mathrm{O}(3)^{b}-\mathrm{Cu}(2)-\mathrm{O}(4)^{a}$ & $87.49(8)$ \\
\hline $\mathrm{O}(2)^{a}-\mathrm{Cu}(1)-\mathrm{O}(4)^{a}$ & $98.01(9)$ & $\mathrm{O}(1)^{c}-\mathrm{Cu}(2)-\mathrm{O}(4)^{a}$ & $157.00(8)$ \\
\hline $\mathrm{O}(2)-\mathrm{Cu}(1)-\mathrm{O}(4)$ & $98.01(9)$ & $\mathrm{O}(5)-\mathrm{Cu}(2)-\mathrm{O}(4)^{a}$ & $92.00(8)$ \\
\hline $\mathrm{O}(2)^{a}-\mathrm{Cu}(1)-\mathrm{O}(4)$ & 81.99(9) & $\mathrm{O}(3)^{b}-\mathrm{Cu}(2)-\mathrm{O}(2)$ & $99.22(8)$ \\
\hline $\mathrm{O}(4)^{a}-\mathrm{Cu}(1)-\mathrm{O}(4)$ & 180 & $\mathrm{O}(1)^{c}-\mathrm{Cu}(2)-\mathrm{O}(2)$ & $132.45(8)$ \\
\hline $\mathrm{O}(3)^{b}-\mathrm{Cu}(2)-\mathrm{O}(1)^{c}$ & $88.93(8)$ & $\mathrm{O}(5)-\mathrm{Cu}(2)-\mathrm{O}(2)$ & $84.85(8)$ \\
\hline $\mathrm{O}(3)^{b}-\mathrm{Cu}(2)-\mathrm{O}(5)$ & $175.45(9)$ & $\mathrm{O}(4)^{a}-\mathrm{Cu}(2)-\mathrm{O}(2)$ & $70.53(7)$ \\
\hline \multicolumn{4}{|c|}{$\begin{array}{l}{ }^{a} \text { Symmetry transformation used to generate equivalent atoms: }-x \text {, } \\
-y+1,-z+1 .{ }^{b} \text { Symmetry transformation used to generate equivalent } \\
\text { toms: } x,-y+3 / 2, z-1 / 2 .{ }^{c} \text { Symmetry transformation used to } \\
\text { enerate equivalent atoms: }-x+1,-y+1,-z+1 .{ }^{d} \text { Symmetry } \\
\text { ansformation used to generate equivalent atoms: } x,-y+3 / 2, z+1 / 2 \text {. }\end{array}$} \\
\hline
\end{tabular}

more usually the case that the carboxylate binds to metal atoms in adjacent layers thereby forming "pillars" between the layers.

The layers are held together by interlayer hydrogen bonding in which the donor atom is $\mathrm{O}(5)$ from the water molecule and the acceptor is a carboxylate oxygen $\mathrm{O}(4)$ in the next layer, as shown by the dotted lines in Figure 3. Additionally, intralayer hydrogen bonding is observed between $\mathrm{O}(5)$ and $\mathrm{O}(6)$. Details of hydrogen bonds are given in Table 6 .

Structure of $\mathrm{Cu}_{1.5}\left(\mathrm{O}_{3} \mathrm{PCH}_{2} \mathrm{CO}_{2}\right) \cdot \mathrm{H}_{2} \mathrm{O}$ (2). Single crystal structural analysis of the green block crystals of $\beta-\mathrm{Cu}_{1.5^{-}}$ $\left(\mathrm{O}_{3} \mathrm{PCH}_{2} \mathrm{CO}_{2}\right) \cdot \mathrm{H}_{2} \mathrm{O}$ reveal that the material crystallizes in the monoclinic space group, $P 2_{1} / c$. Crystallographic data are given in Table 1 with selected bond lengths and angles in Table 3.

The asymmetric unit of 2 contains (Figure 4, upper) 11 nonhydrogen atoms with two crystallographically distinct $\mathrm{Cu}$ environments: $\mathrm{Cu}(2)$ is 5-coordinated, whereas the other, $\mathrm{Cu}(1)$,
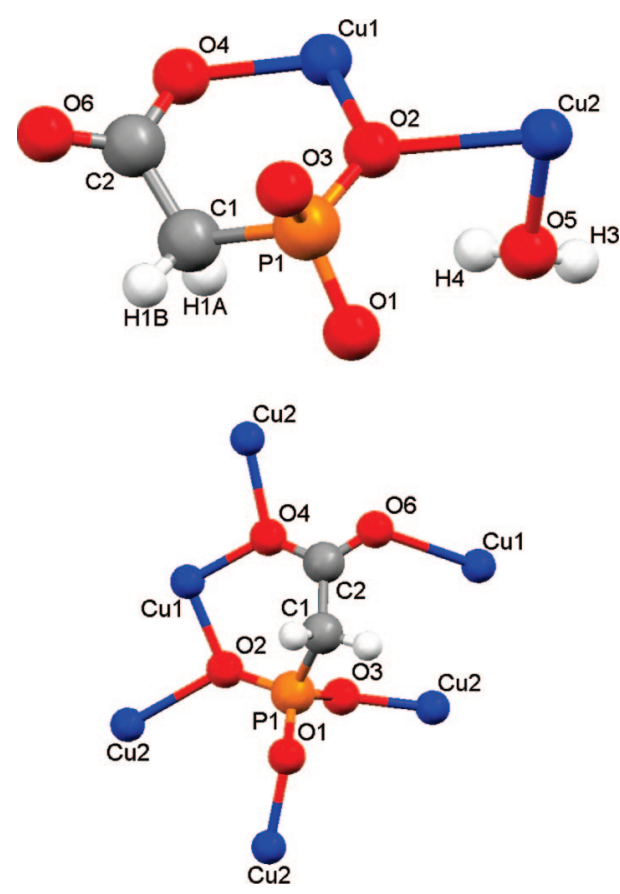

Figure 4. Asymmetric unit of $\mathrm{Cu}_{1.5}\left(\mathrm{O}_{3} \mathrm{PCH}_{2} \mathrm{CO}_{2}\right) \cdot \mathrm{H}_{2} \mathrm{O}(\mathbf{2}$, upper) and the coordination mode of phosphonoacetate (lower).

located on an inversion center, is 6-coordinated. The ligand coordinates to six $\mathrm{Cu}^{2+}$ ions (Figure 4, lower).

The polyhedra are linked in distinct groups of three, as seen in the $\alpha$-form, but in this case the outer two polyhedra are distorted $\mathrm{CuO}_{5}$ trigonal bipyramids. These edge-share with a central octahedral $\mathrm{CuO}_{6}$ unit. Unlike 1 the three-polyhedron subunits are not joined in a step fashion to form chains. Instead chains are formed, as they are linked in the $a$ direction, via $\mathrm{O}-\mathrm{P}-\mathrm{O}$ bridges thereby forming eight-membered rings at either end of the subunit. In this manner extended chains are formed in the [100] direction. The third oxygen atom of the $-\mathrm{PO}_{3}$ group, $\mathrm{O}(3)$, is coordinated to a $\mathrm{Cu}$ atom in a neighboring chain. The carboxylate group again reinforces the cross-linking of the chains with the oxygen atoms $(\mathrm{O}(4)$ and $\mathrm{O}(6))$ linking to $\mathrm{Cu}$ atoms in 


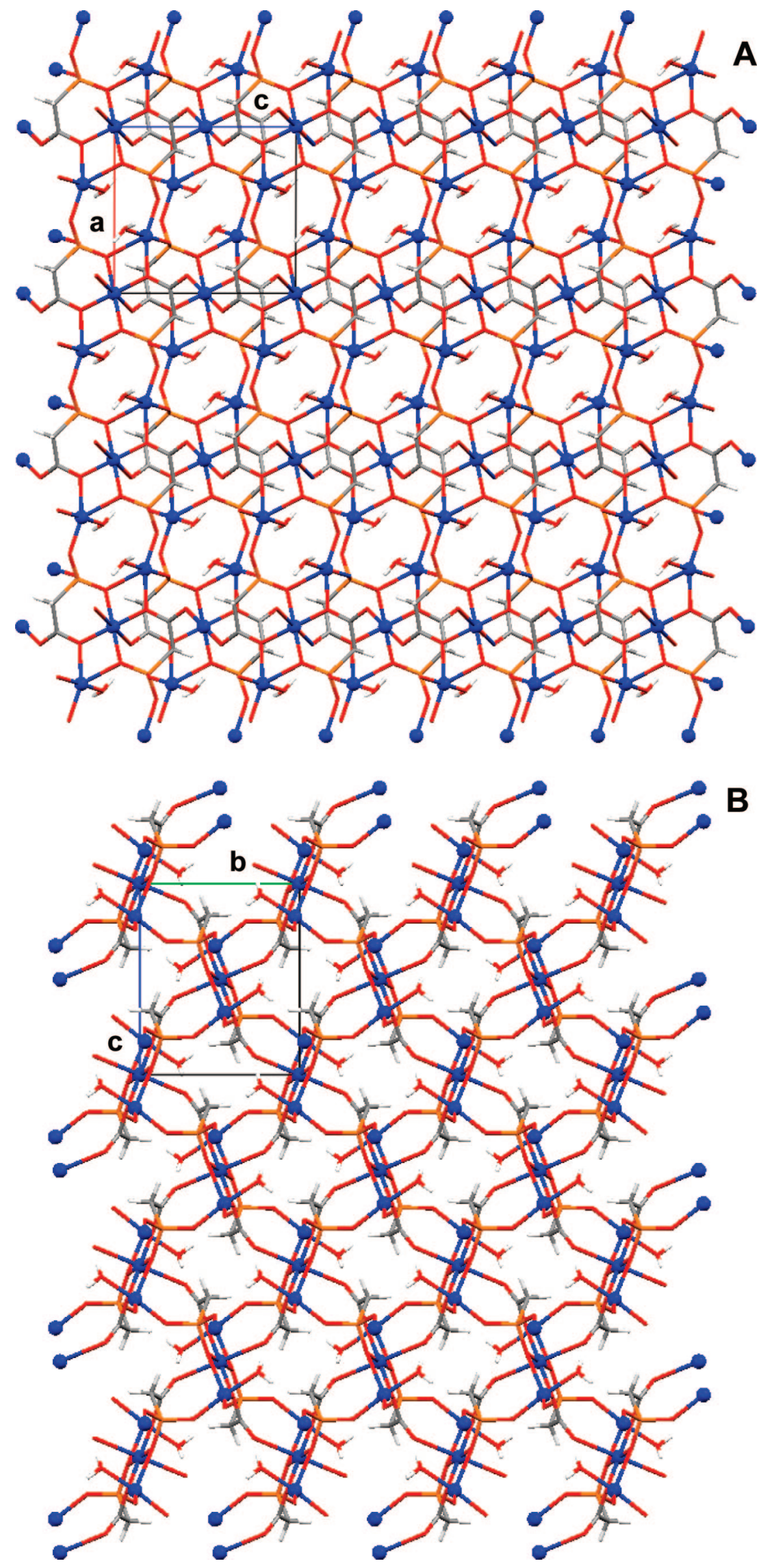

Figure 5. View of $\mathrm{Cu}_{1.5}\left(\mathrm{O}_{3} \mathrm{PCH}_{2} \mathrm{CO}_{2}\right) \cdot \mathrm{H}_{2} \mathrm{O}$ (2) in the [010] direction (upper, A), and in the [100] direction (lower, B).

adjacent chains. In this material, unlike the $\alpha$-phase, the lengths of the $\mathrm{C}-\mathrm{O}$ bonds differ somewhat: $\mathrm{C}(2)-\mathrm{O}(4) 1.303 \AA$ and
$\mathrm{C}(2)-\mathrm{O}(6) 1.231 \AA$. The bonds between those oxygen atoms and copper show the opposite relationship: $\mathrm{Cu}(1)-\mathrm{O}(4) 1.950$ 
Table 4. Bond Lengths $[\AA]$ and Angles [deg] for $\mathrm{Cu}\left(\mathrm{HO}_{3} \mathrm{PCH}_{2} \mathrm{CO}_{2}\right) \cdot \mathrm{H}_{2} \mathrm{O}(3)$

\begin{tabular}{llll}
\hline \multicolumn{5}{c}{ Bonds } \\
\hline $\mathrm{Cu}(1)-\mathrm{O}(1)$ & $1.9139(18)$ & $\mathrm{P}(1)-\mathrm{O}(2)$ & $1.565(2)$ \\
$\mathrm{Cu}(1)-\mathrm{O}(5)$ & $1.9427(19)$ & $\mathrm{P}(1)-\mathrm{C}(1)$ & $1.806(3)$ \\
$\mathrm{Cu}(1)-\mathrm{O}(3)^{a}$ & $1.9456(19)$ & $\mathrm{O}(3)-\mathrm{Cu}(1)^{c}$ & $1.9456(19)$ \\
$\mathrm{Cu}(1)-\mathrm{O}(4)$ & $1.968(2)$ & $\mathrm{O}(3)-\mathrm{Cu}(1)^{b}$ & $2.3834(18)$ \\
$\mathrm{Cu}(1)-\mathrm{O}(3)^{b}$ & $2.3834(18)$ & $\mathrm{O}(5)-\mathrm{C}(2)$ & $1.259(3)$ \\
$\mathrm{P}(1)-\mathrm{O}(1)$ & $1.5083(19)$ & $\mathrm{O}(6)-\mathrm{C}(2)$ & $1.267(3)$ \\
$\mathrm{P}(1)-\mathrm{O}(3)$ & $1.5176(19)$ & $\mathrm{C}(2)-\mathrm{C}(1)$ & $1.513(3)$ \\
\hline \multicolumn{5}{c}{ Angles } \\
\hline $\mathrm{O}(1)-\mathrm{Cu}(1)-\mathrm{O}(5)$ & $93.99(8)$ & $\mathrm{O}(3)^{a}-\mathrm{Cu}(1)-\mathrm{O}(4)$ \\
$\mathrm{O}(1)-\mathrm{Cu}(1)-\mathrm{O}(3)^{a}$ & $175.79(7)$ & $\mathrm{O}(1)-\mathrm{Cu}(1)-\mathrm{O}(3)^{b}$ & $90.75(9)$ \\
$\mathrm{O}(5)-\mathrm{Cu}(1)-\mathrm{O}(3)^{a}$ & $89.81(8)$ & $\mathrm{O}(5)-\mathrm{Cu}(1)-\mathrm{O}(3)^{b}$ & $99.13(7)$ \\
$\mathrm{O}(1)-\mathrm{Cu}(1)-\mathrm{O}(4)$ & $86.07(9)$ & $\mathrm{O}(3)^{a}-\mathrm{Cu}(1)-\mathrm{O}(3)^{b}$ & $82.14(7)$ \\
$\mathrm{O}(5)-\mathrm{Cu}(1)-\mathrm{O}(4)$ & $164.65(10)$ & $\mathrm{O}(4)-\mathrm{Cu}(1)-\mathrm{O}(3)^{b}$ & $96.14(9)$
\end{tabular}

${ }^{a}$ Symmetry transformation used to generate equivalent atoms: $x-1$, $y, z .{ }^{b}$ Symmetry transformation used to generate equivalent atoms: $-x$ $+2,-y+1,-z+2 .{ }^{c}$ Symmetry transformation used to generate equivalent atoms: $x+1, y, z$.
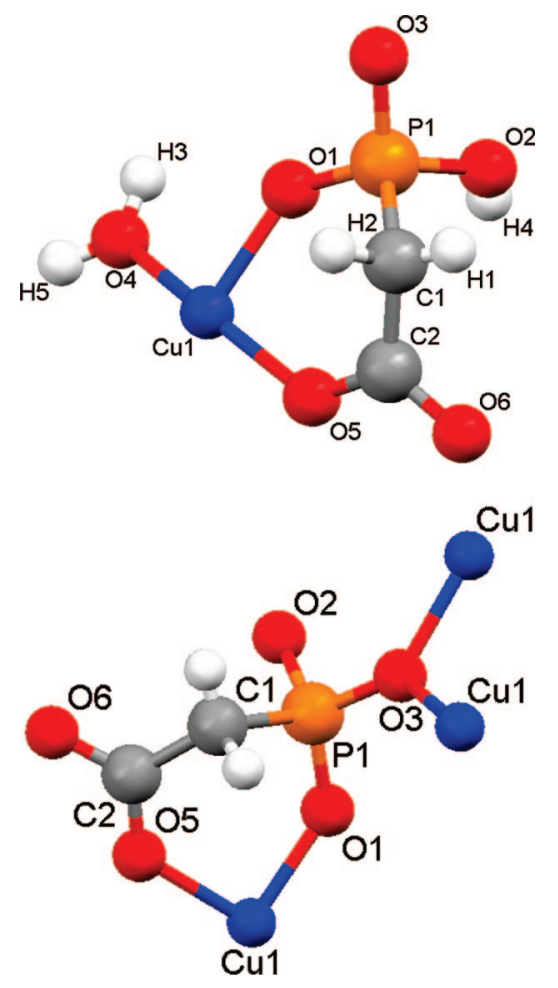

Figure 6. Asymmetric unit of $\mathrm{Cu}\left(\mathrm{HO}_{3} \mathrm{PCH}_{2} \mathrm{CO}_{2}\right) \cdot \mathrm{H}_{2} \mathrm{O}(3$, upper $)$ and the ligand coordination mode (lower).

$\AA$ and $\mathrm{Cu}(1)-\mathrm{O}(6) 2.482 \AA$. Clearly one of the oxygen atoms is more closely associated with the $\mathrm{Cu}$ atoms and the other is more closely associated with the $\mathrm{C}$ atoms.

Viewing the structure along the [010] direction (Figure 5, upper) reveals the presence of narrow channels. The water molecules, O5, that form part of the coordination environment of the 5-coordinated $\mathrm{Cu}$ atom, $\mathrm{Cu}(1)$, are located inside this channel. These molecules are involved in intraframework hydrogen bond formation with oxygen atoms on the phosphate $\mathrm{O}(1)$ and $\mathrm{O}(3)$ and carboxylate $\mathrm{O}(6)$ groups. Details of hydrogen bonds are given in Table 6 . View of the structure along the [100] direction is shown in Figure 5, lower.

Structure of $\mathrm{Cu}\left(\mathrm{HO}_{3} \mathrm{PCH}_{2} \mathrm{CO}_{2}\right) \cdot \mathrm{H}_{2} \mathrm{O}$ (3). The asymmetric unit of $\mathrm{Cu}\left(\mathrm{HO}_{3} \mathrm{PCH}_{2} \mathrm{CO}_{2}\right) \cdot \mathrm{H}_{2} \mathrm{O}$ contains 10 non-hydrogen atoms, and crystallizes in the triclinic $P \overline{1}$ (No.2) space group.
The crystallographic data are summarized in Table 1, and selected bond lengths and angles are given in Table 4 .

The asymmetric unit contains one $\mathrm{Cu}$ atom, which is coordinated by oxygen atoms from phosphonate, carboxylate, and water (Figure 6, upper). The ligand coordinates to three $\mathrm{Cu}^{2+}$ ions (Figure 6, lower).

At first glance it would appear that it has a Jahn-Teller distorted octahedral coordination environment (Figure 7). The four equatorial $\mathrm{Cu}-\mathrm{O}$ bond lengths are in the range 1.914-1.968 $\AA$. The two axial $\mathrm{Cu}-\mathrm{O}$ distances are 2.383 and $2.864 \AA$. The latter of these appears rather long; hence, the question arises as to whether or not this is a bond. Bond valence calculations ${ }^{32}$ were carried out for the $\mathrm{Cu}$ atom in 5- (square pyramidal) and 6-coordinated (octahedral) environments. The calculations returned a value of 2.113 for the 5-coordinated case and 2.154 for the 6-coordinated $\mathrm{Cu}$ atom. While there is little difference between the values obtained (the long axial bond contributes little to the valence sum), the general structure type of this material is dependent upon the way in which the coordination of the $\mathrm{Cu}$ atoms is defined. If the $\mathrm{Cu}$ atom is considered as 6-coordinated, the material is best described as being layered. Consideration of a 5-coordinated $\mathrm{Cu}$ atom would lead to the material being described as having a chain structure.

A further point to consider is the $\mathrm{Cu}$-water interactions. It would appear that the water $\mathrm{O}$ atom is shared between two neighboring $\mathrm{Cu}$ atoms. The water molecule is involved in hydrogen-bonding (vide infra), which leads to the conclusion that it is not shared between the $\mathrm{Cu}$ atoms, and that the material is best described as having chain structure.

Two $\mathrm{Cu}$ atoms are connected by the $\mathrm{O}(3)$ atoms of the phosphonate $-\mathrm{PO}_{3}$ group to form a $\mathrm{Cu}_{2} \mathrm{O}_{2}$ rectangular motif (Figure 7, upper). The $-\mathrm{PO}_{3}$ group of the phosphonate anion exhibits unusual (210) connectivity. ${ }^{31}$ One of the oxygens, $\mathrm{O}(3)$, is thus shared between two $\mathrm{Cu}$ atoms, and it is these that form the rectangular motifs. The second, $\mathrm{O}(1)$, connects to a single $\mathrm{Cu}$ atom in a different motif, thereby propagating the chain, and the final oxygen $\mathrm{O}(2)$ is protonated and is not connected to any metal atoms. Connectivities (111), (112), and (122) have been reported for Zn-carboxyphosphonates. ${ }^{31}$ The phosphonate anions act as bidentate ligands, with the $\mathrm{Cu}$ atoms being coordinated by two oxygens from the same phosphonate anions; the shared $-\mathrm{PO}_{3}$ oxygen and one of the carboxylate oxygens $\mathrm{O}(5)$.

The chains, which are aligned along the $a$ axis (Figure 7, lower), are held together by hydrogen bonding (Figure 8). The hydrogen bonding network consists of three bonds, between three oxygen atoms in a triangular arrangement. An inspection of the structure, viewed in the $a$ direction shows that each chain is connected to six other chains by hydrogen bonding, forming a distorted hexagonal array of chains.

Structure of $\left[\mathrm{Cu}\left(\mathrm{R}, \mathrm{S}-\mathrm{HO}_{3} \mathrm{PCH}(\mathrm{OH}) \mathrm{CO}_{2}\right)\left(\mathrm{H}_{2} \mathrm{O}\right)_{2}\right] \cdot \mathrm{H}_{2} \mathrm{O}$ (4). The asymmetric unit of $\mathbf{4}$ is shown in Figure 9, upper. The ligand coordinates to two $\mathrm{Cu}^{2+}$ ions in a chelating/bridging fashion (Figure 9, lower). Bond distances and angles are provided in Table 5. The $\mathrm{Cu}^{2+}$ centers are located in a distorted octahedral environment shaped by a chelating bidentate HPAA (phosphonate $\mathrm{O}(6)$ and carboxylate $\mathrm{O}(3)$ ), a unidentate carboxylate $\mathrm{O}(2)$ and a protonated hydroxyl group $\mathrm{O}(1)$ (from a neighboring HPAA), and two water molecules $\mathrm{O}(7)$ and $\mathrm{O}(8)$. The HPAA ligand is doubly deprotonated and has lost one proton from the carboxylic acid and one from the phosphonic acid moieties. HPAA forms a 6-membered ring through its phosphonate and carboxylate oxygens (see Figure 9). The $\mathrm{Cu}-\mathrm{O}$ (phosphonate) distance is 1.9687 . The $\mathrm{Cu}-\mathrm{O}$ (carboxyl) 

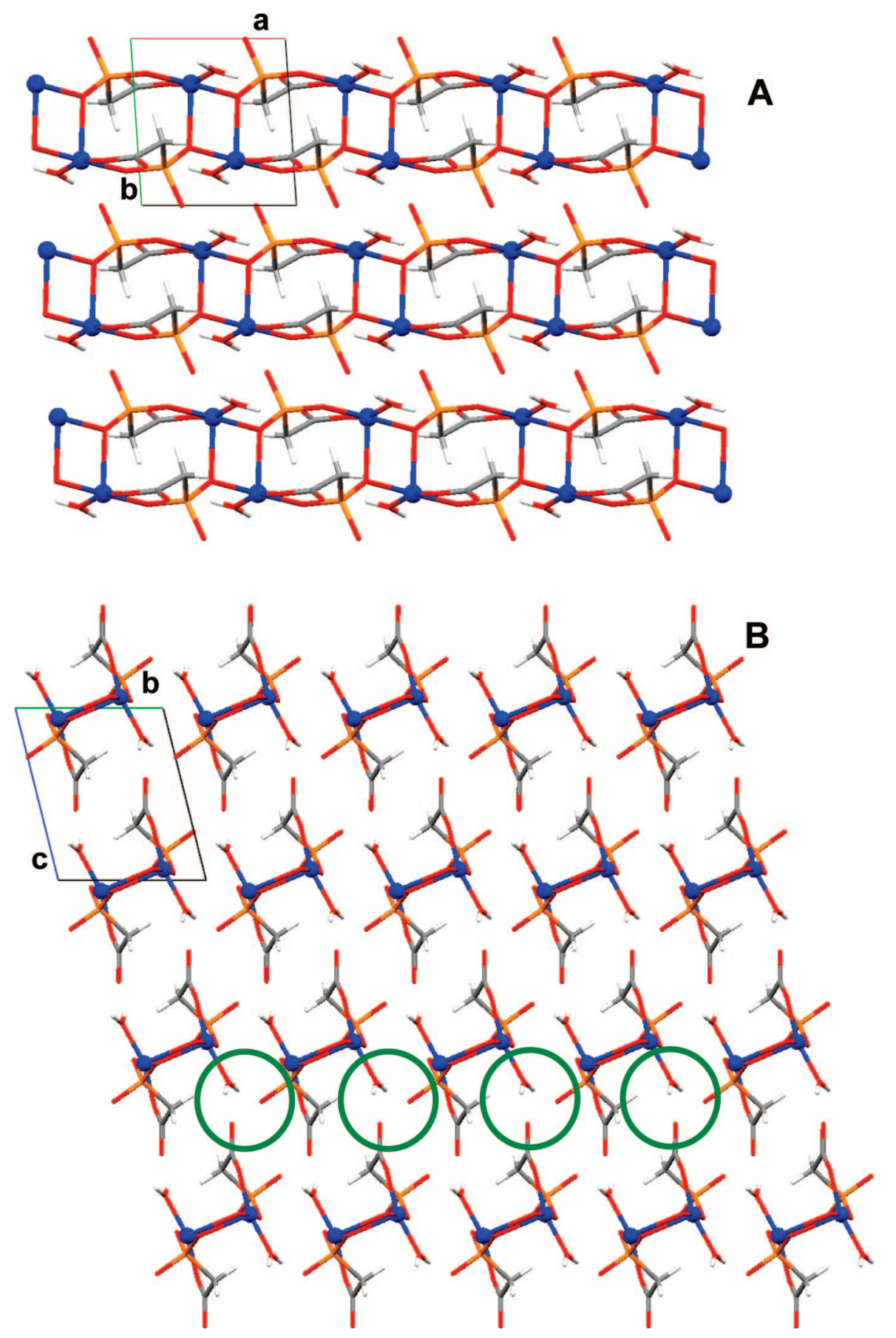

Figure 7. Chain structure of $\mathrm{Cu}\left(\mathrm{HO}_{3} \mathrm{PCH}_{2} \mathrm{CO}_{2}\right) \cdot \mathrm{H}_{2} \mathrm{O}(3)$ viewed along the $c$ axis (upper, A) and along the $a$ axis (lower, B).

bond distances are $\mathrm{Cu}-\mathrm{O}(2) 1.9963 \AA$ and $\mathrm{Cu}-\mathrm{O}$ (3) 1.9762 $\AA$, whereas the $\mathrm{Cu}-\mathrm{O}$ (hydroxyl) distance is at $2.2116 \AA$. A metal-O(hydroxyl) coordination feature has been reported for $\left[\mathrm{NH}_{2} \mathrm{CH}_{2} \mathrm{CH}_{2} \mathrm{NH}_{2}\right]\left[\mathrm{Sb}_{2}\left(\mathrm{O}_{3} \mathrm{PCH}(\mathrm{OH}) \mathrm{CO}_{2}\right)_{2}\right] .{ }^{33} \mathrm{The} \mathrm{Cu}-\mathrm{O}$ (water) bond distances are 1.972 and $2.457 \AA$. The long $\mathrm{Cu}-\mathrm{O}$ (hydroxyl) and $\mathrm{Cu}-\mathrm{O}$ (water) bond distances are a demonstration of the Jahn-Teller effect in the solid state. Finally, the $\mathrm{C}-\mathrm{O}$ bond lengths in the carboxyl group are very similar, 1.268 and 1.253 $\AA$, indicating that the negative charge is delocalized over both $\mathrm{O}$ atoms.

Material 4 has a 1D chain structure formed by a combination of chelating and bridging coordination modes of $\mathrm{HPAA}^{2-}$. Each $\mathrm{HPAA}^{2-}$ acts as a tetradentate ligand bridging to $\mathrm{Cu}$ centers. The intrachain $\mathrm{Cu} \cdots \mathrm{Cu}$ distance is $5.774 \AA$, whereas the closest interchain $\mathrm{Cu} \cdots \mathrm{Cu}$ distance is $5.366 \AA$. Both $S$ and $R$ enanti- omers are found incorporated in the structure of 4 . This is not surprising because a racemic mixture of HPAA was used in synthesis. However, at a closer look there are some noteworthy features in the structure of $\mathbf{4}$. The chains run along the $a$ axis. Each chain incorporates both $S$ and $R$ HPAA enantiomers in a...-S-R-S-R-S-... alternating fashion. There are right- and lefthanded helices in the structure of 4 . This feature is shown in a simplified form in Figure 10. A similar feature has been noted in the structure of the ladder-type $\left(\mathrm{NH}_{4}\right) \mathrm{Zn}\left[\mathrm{O}_{3} \mathrm{PCH}(\mathrm{OH}) \mathrm{CO}_{2}\right]{ }^{34}$

The 1D chains are held together with a complicated network of hydrogen bonds (see Table 6) that principally involve the waters of crystallization located between the layers (each forms four hydrogen bonds, two with the $\mathrm{Cu}$-coordinated phosphonate oxygen and two with the $\mathrm{Cu}$-coordinated water, Figure 11). 


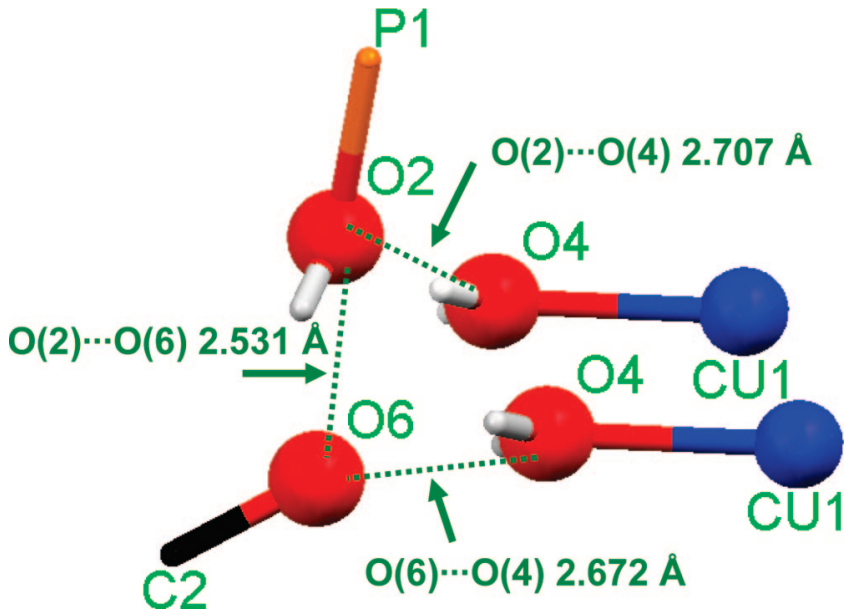

Figure 8. Hydrogen bonding (dashed lines) holding the chains together in $\mathbf{3}$ in the region highlighted in the circle in Figure 7.

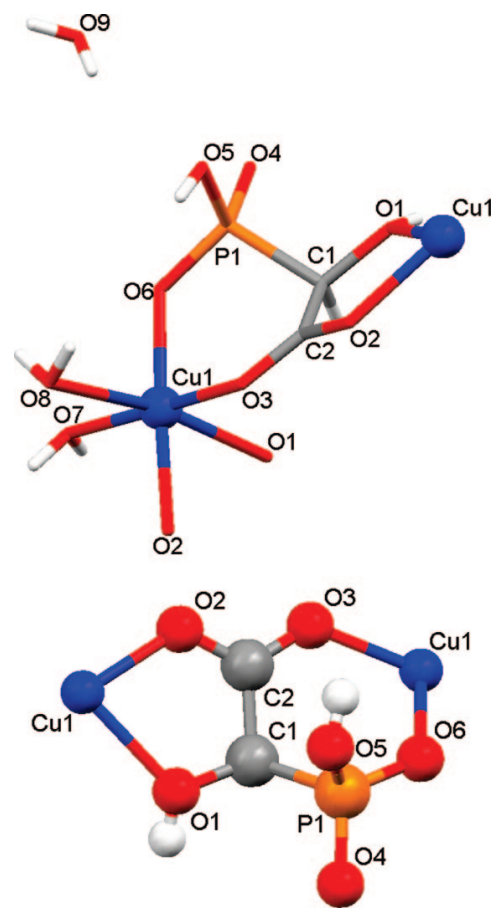

Figure 9. Asymmetric unit of $\left[\mathrm{Cu}\left(\mathrm{HO}_{3} \mathrm{PCH}(\mathrm{OH}) \mathrm{CO}_{2}\right)\left(\mathrm{H}_{2} \mathrm{O}\right)_{2}\right] \cdot \mathrm{H}_{2} \mathrm{O}(4$, upper) and the ligand chelating/bridging coordination mode (lower).

Infra-Red Vibrational Spectroscopy. The position of the carbonyl stretching peak in the IR spectrum of materials containing such bonding, is a good indicator with regard to whether or not the carbonyl group is free, involved in hydrogen bonding or coordinated to a metal atom. The IR spectrum of diethyl phosphonoacetic acid has a single, strong, sharp band corresponding to the stretching of the carbonyl bond, located at $1732 \mathrm{~cm}^{-1}$. HPAA has a strong $v(\mathrm{C}=\mathrm{O})$ band at $1734 \mathrm{~cm}^{-1}$ and a set of four bands (946, 1006, 1091, and $1189 \mathrm{~cm}^{-1}$ ) assigned to a combination of $\mathrm{P}-\mathrm{O}$ and $\mathrm{P}=\mathrm{O}$ stretching vibrations.

In the IR spectra of both $\mathrm{Cu}_{1.5}\left(\mathrm{O}_{3} \mathrm{PCH}_{2} \mathrm{CO}_{2}\right) \cdot \mathrm{H}_{2} \mathrm{O}$ materials (1 and 2) the position of the carbonyl band is shifted to lower frequencies, as would be expected from the structure of these materials. In the $\alpha$-phase a single sharp band is seen at 1576 $\mathrm{cm}^{-1}$, arising from the fact that the $\mathrm{C}-\mathrm{O}$ bonds are approximately the same length and in both cases the oxygen is coordinated to a $\mathrm{Cu}$ atom.
Table 5. Bond Lengths $[\AA]$ and Angles [deg] for $\left[\mathrm{Cu}\left(\mathrm{HO}_{3} \mathrm{PCH}(\mathrm{OH}) \mathrm{CO}_{2}\right)\left(\mathrm{H}_{2} \mathrm{O}\right)_{2}\right] \cdot \mathrm{H}_{2} \mathrm{O}(4)$

\begin{tabular}{llll}
\hline \multicolumn{5}{c}{ Bonds } \\
\hline $\mathrm{Cu}(1)-\mathrm{O}(6)$ & $1.9687(18)$ & $\mathrm{C}(1)-\mathrm{O}(1)$ & $1.417(3)$ \\
$\mathrm{Cu}(1)-\mathrm{O}(7)$ & $1.9719(19)$ & $\mathrm{C}(1)-\mathrm{C}(2)$ & $1.521(3)$ \\
$\mathrm{Cu}(1)-\mathrm{O}(3)$ & $1.9762(17)$ & $\mathrm{C}(2)-\mathrm{O}(3)$ & $1.253(3)$ \\
$\mathrm{Cu}(1)-\mathrm{O}(2) \# 1^{a}$ & $1.9963(17)$ & $\mathrm{C}(2)-\mathrm{O}(2)$ & $1.268(3)$ \\
$\mathrm{Cu}(1)-\mathrm{O}(1) \# 1^{a}$ & $2.2116(17)$ & $\mathrm{P}(1)-\mathrm{O}(4)$ & $1.4931(18)$ \\
$\mathrm{Cu}(1)-\mathrm{O}(8)$ & $2.457(19)$ & $\mathrm{P}(1)-\mathrm{O}(6)$ & $1.5212(18)$ \\
$\mathrm{P}(1)-\mathrm{C}(1)$ & $1.833(3)$ & $\mathrm{P}(1)-\mathrm{O}(5)$ & $1.5664(19)$ \\
\hline \multicolumn{5}{c}{ Angles } \\
$\mathrm{O}(6)-\mathrm{Cu}(1)-\mathrm{O}(7)$ & $88.98(8)$ & $\mathrm{O}(3)-\mathrm{Cu}(1)-\mathrm{O}(2) \# 1^{a}$ & $88.04(7)$ \\
$\mathrm{O}(6)-\mathrm{Cu}(1)-\mathrm{O}(3)$ & $93.32(7)$ & $\mathrm{O}(6)-\mathrm{Cu}(1)-\mathrm{O}(1) \# 1^{a}$ & $99.09(7)$ \\
$\mathrm{O}(7)-\mathrm{Cu}(1)-\mathrm{O}(3)$ & $172.43(8)$ & $\mathrm{O}(7)-\mathrm{Cu}(1)-\mathrm{O}(1) \# 1^{a}$ & $97.16(8)$ \\
$\mathrm{O}(6)-\mathrm{Cu}(1)-\mathrm{O}(2) \# 1^{a}$ & $174.92(7)$ & $\mathrm{O}(3)-\mathrm{Cu}(1)-\mathrm{O}(1) \# 1^{a}$ & $89.60(7)$ \\
$\mathrm{O}(7)-\mathrm{Cu}(1)-\mathrm{O}(2) \# 1^{a}$ & $90.29(8)$ & $\mathrm{O}(2) \# 1-\mathrm{Cu}(1)-\mathrm{O}(1) \# 1^{a}$ & $76.02(6)$
\end{tabular}

${ }^{a}$ Symmetry transformation used to generate equivalent atoms: \#1 $x+$ $1 / 2, y,-z+1 / 2$.

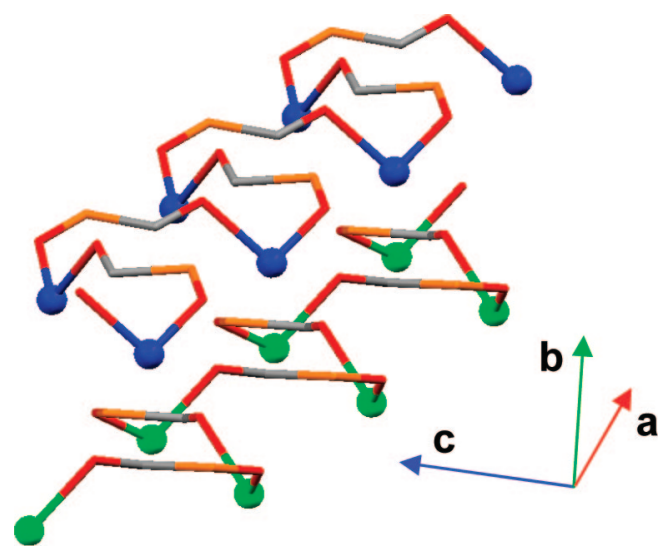

Figure 10. Left-handed and right-handed helices in the structure of $\left[\mathrm{Cu}\left(\mathrm{HO}_{3} \mathrm{PCH}(\mathrm{OH}) \mathrm{CO}_{2}\right)\left(\mathrm{H}_{2} \mathrm{O}\right)_{2}\right] \cdot \mathrm{H}_{2} \mathrm{O}(4)$. Only the bonds that form the chains are shown, for clarity. $\mathrm{Cu}^{2+}$ centers from the two neighboring helices are shown in blue and green.

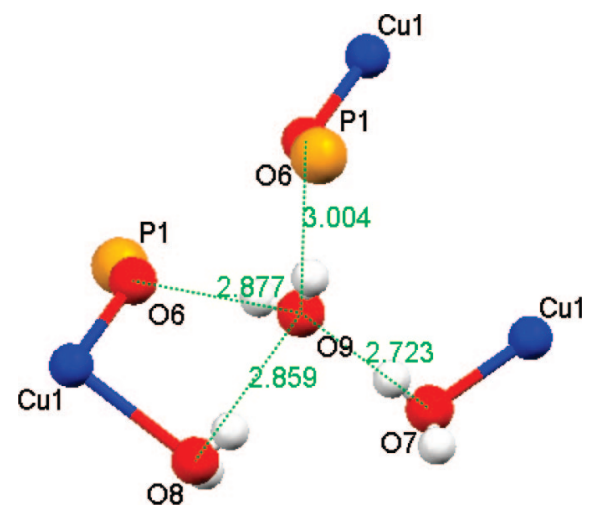

Figure 11. Hydrogen bonding (dashed lines) involving a water of crystallization holding the chains together in $\mathbf{4}$.

In the $\beta$-phase the $\mathrm{C}-\mathrm{O}$ distances are significantly different, implying that one bond has a higher bond order. The IR spectrum contains a strong sharp peak at $1630 \mathrm{~cm}^{-1}$, with a shoulder at $1575 \mathrm{~cm}^{-1}$. The higher frequency peak has been assigned as that arising from the shorter $\mathrm{C}=\mathrm{O}$ bond.

The IR spectrum of $\mathrm{Cu}\left(\mathrm{HO}_{3} \mathrm{PCH}_{2} \mathrm{CO}_{2}\right) \cdot \mathrm{H}_{2} \mathrm{O}(3)$ contains a broad peak at $1565 \mathrm{~cm}^{-1}$. The $\mathrm{C}-\mathrm{O}$ bonds in the phosphonate anion are similar in length; $\mathrm{C}(2)-\mathrm{O}(5) 1.259 \AA, \mathrm{C}(2)-\mathrm{O}(6)$ $1.267 \AA$. The main difference between them is the fact that one oxygen is coordinated directly to a $\mathrm{Cu}$ atom while the other is 
Table 6. Hydrogen Bond Lengths [̊̊] and Angles [deg] for All Materials

\begin{tabular}{|c|c|c|c|c|c|}
\hline compound & bond $(\mathrm{D}-\mathrm{H} \cdots \mathrm{A})$ & $\mathrm{D}-\mathrm{H} / \AA$ & $\mathrm{H} \cdots \mathrm{A} / \AA ̊$ & $\mathrm{D} \cdots \mathrm{A} / \AA ̊$ & $\angle \mathrm{D}-\mathrm{H}-\mathrm{A} / \mathrm{deg}$ \\
\hline \multirow[t]{2}{*}{ (1) } & $\mathrm{O}(5)-\mathrm{H}(4) \cdots \mathrm{O}(4)^{a}$ & $0.86(6)$ & $1.84(6)$ & $2.677(5)$ & $163(5)$ \\
\hline & $\mathrm{O}(5)-\mathrm{H}(3) \cdots \mathrm{O}(6)^{b}$ & $0.71(6)$ & $2.31(6)$ & $2.907(4)$ & $143(6)$ \\
\hline (2) & $\mathrm{O}(5)-\mathrm{H}(3) \cdots \mathrm{O}(1)^{c}$ & $0.79(5)$ & $2.10(5)$ & $2.869(3)$ & $166(4)$ \\
\hline \multirow[t]{3}{*}{ (3) } & $\mathrm{O}(4)-\mathrm{H}\left(4^{a}\right) \cdots \mathrm{O}(2)^{e}$ & $0.90(4)$ & $1.81(4)$ & $2.707(3)$ & $172(3)$ \\
\hline & $\mathrm{O}(2)-\mathrm{H}(2) \cdots \mathrm{O}(6)^{f}$ & $0.84(1)$ & $1.73(1)$ & $2.531(3)$ & $157(4)$ \\
\hline & $\mathrm{O}(4)-\mathrm{H}(4 \mathrm{~b}) \cdots \mathrm{O}(6)^{g}$ & $0.68(4)$ & $2.40(4)$ & $3.074(3)$ & $170(4)$ \\
\hline \multirow{3}{*}{ (4) } & $\mathrm{O}(9)-\mathrm{H}(9 \mathrm{~b}) \cdots \mathrm{O}(6)^{k}$ & $0.73(3)$ & $2.32(3)$ & $3.004(3)$ & $158(4)$ \\
\hline & $\mathrm{O}(8)-\mathrm{H}(8 \mathrm{a}) \cdots \mathrm{O}(9)^{l}$ & $0.72(3)$ & $2.19(3)$ & $2.859(3)$ & $155(4)$ \\
\hline & $\mathrm{O}(8)-\mathrm{H}(8 \mathrm{~b}) \cdots \mathrm{O}(4)^{m}$ & $0.77(3)$ & $2.05(3)$ & $2.810(3)$ & $168(4)$ \\
\hline
\end{tabular}

Symmetry transformation used to generate equivalent atoms: ${ }^{a}$ Symmetry transformation used to generate equivalent atoms: $x, y-1, z .{ }^{b}$ Symmetry transformation used to generate equivalent atoms: $1-x, 1-y,-z \cdot{ }^{c}$ Symmetry transformation used to generate equivalent atoms: $x, 1 / 2-y, z-1 / 2$. ${ }^{d}$ Symmetry transformation used to generate equivalent atoms: $-x, y-1 / 2,3 / 2-z .{ }^{e}$ Symmetry transformation used to generate equivalent atoms: $2-$ $x, 2-y, 1-z \cdot{ }^{f}$ Symmetry transformation used to generate equivalent atoms: $2-x, 2-y, 2-z .{ }^{g}$ Symmetry transformation used to generate equivalent atoms: $1-x, y, 1+z .{ }^{h}$ Symmetry transformation used to generate equivalent atoms: $1+x, y, z .{ }^{i}$ Symmetry transformation used to generate equivalent atoms: $5 / 2-x,-1 / 2+y, z \cdot{ }^{j}$ Symmetry transformation used to generate equivalent atoms: $-1 / 2+x, 1 / 2-y, 1-z \cdot{ }^{k}$ Symmetry transformation used to generate equivalent atoms: $3 / 2-x, 1 / 2+y, z \cdot{ }^{l}$ Symmetry transformation used to generate equivalent atoms: $1 / 2+x, 1 / 2-y, 1$ $-z \cdot{ }^{m}$ Symmetry transformation used to generate equivalent atoms: $3 / 2-x, 1 / 2+y, z$.

involved in the hydrogen bonding network holding the chains together. It is likely that the involvement of $\mathrm{O}(6)$ in hydrogen bonding is responsible for the broadening of the $\mathrm{C}-\mathrm{O}$ stretching band in the IR spectrum.

The IR spectrum of $\left[\mathrm{Cu}\left(R, S-\mathrm{HO}_{3} \mathrm{PCH}(\mathrm{OH}) \mathrm{CO}_{2}\right)\left(\mathrm{H}_{2} \mathrm{O}\right)_{2}\right] \cdot \mathrm{H}_{2} \mathrm{O}$ (4) contains a number of important features. The $v(\mathrm{O}-\mathrm{H})$ bands are found at 3455 and $3551 \mathrm{~cm}^{-1}$ superimposed on a much broader band from 3030 to $3570 \mathrm{~cm}^{-1}$. This is consistent with the plethora of hydrogen bonds involving both coordinated and lattice water molecules. A weak broad band at $2292 \mathrm{~cm}^{-1}$ is assigned to the $\mathrm{P}-\mathrm{OH}$ stretch. The $v(\mathrm{C}=\mathrm{O})$ stretches are found at 1626 and $1562 \mathrm{~cm}^{-1}$. This differentiation can be rationalized by examining the closest $\mathrm{H}$-bonding contacts of the two carboxylate $\mathrm{O}$ 's, $\mathrm{O}(2)$ and $\mathrm{O}(3)$. $\mathrm{O}(3)$ does not participate in any $\mathrm{H}$ bonds. In contrast, $\mathrm{O}(2)$ is found at a $2.616 \AA$ distance from $\mathrm{O}(1)$ (hydroxyl) and $2.813 \AA$ from $\mathrm{O}(7)(\mathrm{Cu}$-coordinated water). It is therefore reasonable to assume that the $1562 \mathrm{~cm}^{-1}$ band is assigned to the $\mathrm{C}(2)-\mathrm{O}(3)$ stretch, whereas the 1626 $\mathrm{cm}^{-1}$ band to the $\mathrm{C}(2)-\mathrm{O}(2)$ stretch. A set of intense peaks in the $940-1185 \mathrm{~cm}^{-1}$ region are assigned to the $\mathrm{P}-\mathrm{O}$ and $\mathrm{P}=\mathrm{O}$ stretching vibrations. Finally, a band in the far-IR region at 337 $\mathrm{cm}^{-1}$ is likely due to $\mathrm{Cu}-\mathrm{O}$ (ligand) vibrations.

In all materials, bands arising from water molecules, $\mathrm{P}-\mathrm{O}$, $\mathrm{P}-\mathrm{C}$, and $\mathrm{C}-\mathrm{H}$ bonds appear in the expected spectral ranges.

Thermal Characterization. The TGA trace of $\mathbf{1}$ shows a stepwise decomposition of the material. The first loss is centered around $80^{\circ} \mathrm{C}$ and corresponds to the loss of the water molecule. The remaining steps arise from the decomposition of the phosphonate anion, and yield a final mass loss of 26.64\%; theoretical loss based on $\mathrm{CHN}$ and single crystal analysis is $23.98 \%$.

The thermal behavior of the second polymorph, $\mathbf{2}$, is quite different from that of $\mathbf{1}$. The loss of water and decomposition of the organic material occurs in a single step that onsets at $300{ }^{\circ} \mathrm{C}$. The overall observed mass loss is $23.87 \%$, which compares well to the theoretical value of $23.98 \%$. For materials 1 and 2 the thermal decomposition product was shown by powder XRD to be $\mathrm{Cu}_{2} \mathrm{P}_{2} \mathrm{O}_{7}$.

$\mathbf{3}$ is also more stable than $\mathbf{1}$ under the conditions employed in the TGA experiments. The material undergoes a stepwise mass loss, with the first loss corresponding to loss of the water molecule, at around $300^{\circ} \mathrm{C}$. This is followed by decomposition of the organic anion over two steps centered at 350 and 500
${ }^{\circ} \mathrm{C}$. The total observed mass loss of $29.84 \%$ compares reasonably well with the theoretical value of $31.45 \%$ (based on the formation of $\mathrm{Cu}_{2} \mathrm{P}_{2} \mathrm{O}_{7}$ ).

4 is stable to $\sim 50{ }^{\circ} \mathrm{C}$, after which it quickly loses the water molecules up to $150{ }^{\circ} \mathrm{C}$. The loss of $\sim 20 \%$ (calculated $19.9 \%$ ) corresponds well to loss of both $\mathrm{Cu}$-coordinated waters and the water of crystallization, in the same step. Beyond $150{ }^{\circ} \mathrm{C}$ the material decomposes in two steps $\left(250-270{ }^{\circ} \mathrm{C}\right.$ and $300-315$ $\left.{ }^{\circ} \mathrm{C}\right)$. The total observed mass loss of $\sim 44 \%$ corresponds well to the calculated $42 \%$ (based on the formation of $\mathrm{Cu}_{2} \mathrm{P}_{2} \mathrm{O}_{7}$ ).

\section{Discussion}

Three copper phosphonoacetates have been synthesized from copper acetate and diethylphosphonoacetic acid, by varying ratio of reactants and the temperature at which the hydrothermal synthesis is carried out. All three have different structures: one is layered, one exhibits a 3D framework, and the last has a chain structure. Considering these materials in conjunction with $\mathrm{K}_{4}\left[\mathrm{Cu}\left(\mathrm{O}_{3} \mathrm{PCH}_{2} \mathrm{CO}_{2}\right)_{2}\left(\mathrm{H}_{2} \mathrm{O}\right)\right] \cdot 4 \mathrm{H}_{2} \mathrm{O}$ shows that the copper/ phosphonoacetate system has a rich structural chemistry exhibiting $1 \mathrm{D}, 2 \mathrm{D}$, and $3 \mathrm{D}$ structures.

Hydrothermal treatment of a $1: 1$ reactant mixture at $160{ }^{\circ} \mathrm{C}$ yields one of two polymorphs of $\mathrm{Cu}_{1.5}\left(\mathrm{O}_{3} \mathrm{PCH}_{2} \mathrm{CO}_{2}\right) \cdot \mathrm{H}_{2} \mathrm{O}, \mathbf{1}$ or $\mathbf{2}$, or a physical mixture of the two phases. Higher reaction temperatures yield only $\mathbf{2}$, whereas lower temperatures yield exclusively 1. There are two possible explanations for these observations. The first is that $\mathbf{1}$ is destroyed as the temperature increases, and the second is that it undergoes a phase change to 2. The latter argument is supported by the fact that the respective layered and framework structures of $\mathbf{1}$ and $\mathbf{2}$ appear to be related to one another, though the relationship is not simple. The nature of the change from one phase to the other is currently under further investigation using in situ energy dispersive X-ray diffraction to observe the formation of the phases inside the autoclave, as part of another study. The results will be presented elsewhere.

$\mathrm{Cu}\left(\mathrm{HO}_{3} \mathrm{PCH}_{2} \mathrm{CO}_{2}\right) \cdot \mathrm{H}_{2} \mathrm{O}(3)$ contains a phoshonoacetate anion which is protonated at the phosphonate end rather than the carboxylate group. Protonation of the phosphate group is also seen in an aluminum methylphosphonate, $\left[\mathrm{Al}\left(\mathrm{HO}_{3} \mathrm{PCH}_{3}\right)\right.$ $\left.\left(\mathrm{O}_{3} \mathrm{PCH}_{3}\right) \cdot \mathrm{H}_{2} \mathrm{O}\right]^{35}$ and one of the $\mathrm{Al}^{3+}$ benzylphosphonates, $\mathrm{Al}_{3} \mathrm{H}\left(\mathrm{O}_{3} \mathrm{PCH}_{2} \mathrm{C}_{6} \mathrm{H}_{5}\right)_{5} \cdot \mathrm{H}_{2} \mathrm{O},{ }^{20}$ reported by Zakowsky et al., 
though in these cases there are no other groups in the phosphonate anion that could accept the proton. Finally, a pentanuclear Mo-phosphonoacetate cluster $\left(\mathrm{Rb}_{4} \mathrm{KNa}\left[\left(\mathrm{O}_{3} \mathrm{PCH}_{2^{-}}\right.\right.\right.$ $\left.\left.\left.\mathrm{CO}_{2}\right)_{2} \mathrm{Mo}_{5} \mathrm{O}_{15}\right] \cdot \mathrm{H}_{2} \mathrm{O}\right)^{36}$ has been recently reported. The title polyanion consists of a ring of five $\mathrm{MoO}_{6}$ octahedra with four edge junctions and one corner junction. This nonplanar arrangement is stabilized by two phosphonocarboxylate groups that are bound via their phosphonate functionalities on opposite sides of the ring. As a result, the two dangling arms with their terminal carboxylate groups are directed away from the Mo-oxo framework in diametrically opposed directions.

$\left[\mathrm{Cu}\left(R, S-\mathrm{HO}_{3} \mathrm{PCH}(\mathrm{OH}) \mathrm{CO}_{2}\right)\left(\mathrm{H}_{2} \mathrm{O}\right)_{2}\right] \cdot \mathrm{H}_{2} \mathrm{O}(4)$ is a one-dimensional system whose structure is composed of left- and righthanded Cu-HPAA helices, which incorporate both $R$ and $S$ enantiomers within a single helix in an alternate fashion. MetalHPAA frameworks have been reported recently for $\mathrm{Sb}^{33}$ $\left(\left[\mathrm{NH}_{2} \mathrm{CH}_{2} \mathrm{CH}_{2} \mathrm{NH}_{2}\right]\left[\mathrm{Sb}_{2}\left(\mathrm{O}_{3} \mathrm{PCH}(\mathrm{OH}) \mathrm{CO}_{2}\right)_{2}\right]\right), \mathrm{Zn}^{34}\left(\left(\mathrm{NH}_{4}\right) \mathrm{Zn}-\right.$ $\left.\left[\mathrm{O}_{3} \mathrm{PCH}(\mathrm{OH}) \mathrm{CO}_{2}\right]\right), \mathrm{Cd}^{37}\left(\mathrm{Na}_{2}\left[\mathrm{Cd}_{2}\left(\mathrm{H}_{2} \mathrm{O}\right)_{3}\left(\mathrm{O}_{3} \mathrm{PCH}(\mathrm{OH}) \mathrm{CO}_{2}\right)_{2}\right] \cdot\right.$ $2 \mathrm{H}_{2} \mathrm{O}, \mathrm{Mg}^{38}\left(\mathrm{Mg}_{0.5} \mathrm{Cd}\left[\mathrm{O}_{3} \mathrm{PCH}(\mathrm{OH}) \mathrm{CO}_{2}\right]\right), \mathrm{Co}^{39}\left(\left[\mathrm{enH}_{2}\right]_{0.5^{-}}\right.$ $\left[\mathrm{Co}\left(\mathrm{O}_{2} \mathrm{CCH}(\mathrm{OH}) \mathrm{PO}_{3}\right)\left(\mathrm{H}_{2} \mathrm{O}\right)\right] \cdot \mathrm{H}_{2} \mathrm{O}$, en $=$ ethylenediamine $)$, $\mathrm{Mn},{ }^{40} \mathrm{Fe},{ }^{40} \mathrm{Co},{ }^{40} \mathrm{Zn}^{40}$ (an isostructural series of materials $\left.\left[\mathrm{M}\left(\mathrm{HO}_{3} \mathrm{PCH}(\mathrm{OH}) \mathrm{CO}_{2}\right)\left(\mathrm{H}_{2} \mathrm{O}\right)_{2}\right]\right), \mathrm{Sr}^{29,41}\left(\mathrm{Sr}\left[\left(\mathrm{HO}_{3} \mathrm{PCH}(\mathrm{OH})-\right.\right.\right.$ $\left.\left.\mathrm{CO}_{2}\right)\left(\mathrm{H}_{2} \mathrm{O}\right)_{3}\right] \cdot \mathrm{H}_{2} \mathrm{O}$ and $\left.\mathrm{Sr}\left[\left(\mathrm{HO}_{3} \mathrm{PCH}(\mathrm{OH}) \mathrm{CO}_{2}\right)\left(\mathrm{H}_{2} \mathrm{O}\right)_{2}\right]\right)$, and $\mathrm{Ba}^{29,41}\left(\mathrm{Ba}\left[\left(\mathrm{HO}_{3} \mathrm{PCH}(\mathrm{OH}) \mathrm{CO}_{2}\right)\left(\mathrm{H}_{2} \mathrm{O}\right)_{2}\right]\right)$. Material 4 is distinctly different from the aforementioned materials in that it forms 1D chains that interact with each other exclusively hydrogen bonds.

\section{Conclusion}

In this manuscript it has been demonstrated that one synthetic system can give rise to a number of different products by the simple means of changing the reaction temperature or reagent ratios. Thus, access to novel compounds $\alpha-\mathrm{Cu}_{1.5}\left(\mathrm{O}_{3} \mathrm{PCH}_{2} \mathrm{CO}_{2}\right) \cdot$ $\mathrm{H}_{2} \mathrm{O}(\mathbf{1}), \beta-\mathrm{Cu}_{1.5}\left(\mathrm{O}_{3} \mathrm{PCH}_{2} \mathrm{CO}_{2}\right) \cdot \mathrm{H}_{2} \mathrm{O}(2)$, and $\mathrm{Cu}\left(\mathrm{HO}_{3} \mathrm{PCH}_{2}-\right.$ $\left.\mathrm{CO}_{2}\right) \cdot \mathrm{H}_{2} \mathrm{O}(3)$ was possible by simply varying reaction conditions (initial solution $\mathrm{pH}$, temperature, reactant ratio). These results complement previous findings reported in the literature. Furthermore, the presence of additional moieties on the ligand backbone may induce profound changes in the structure of the final product. The presence of a hydroxyl group on the phosphonoacetate backbone directs the synthesis to yield $\left[\mathrm{Cu}\left(R, S-\mathrm{HO}_{3} \mathrm{PCH}(\mathrm{OH}) \mathrm{CO}_{2}\right)\left(\mathrm{H}_{2} \mathrm{O}\right)_{2}\right] \cdot \mathrm{H}_{2} \mathrm{O}(4)$. While it may not be true that all phosphonate syntheses will exhibit such behavior, there clearly exists a need for a more systematic approach in the endeavor for novel functional materials.

Acknowledgment. G.B.H. thanks the EPSRC for the provision of a studentship for A.T. and funding of this project. We also thank the EPSRC X-ray Crystallography Service at Southampton for collecting single crystal data and University of London, CHN Elemental Microanalysis Service for their contribution. K.D.D. thanks the General Secretariat of Science \& Technology (Contract \# 2006-207c) for partial funding.

Supporting Information Available: Crystallographic information on the structures, cif files, mid FT-IR spectra, XRD powder patterns, TGA traces. CCDC Reference numbers: $\mathrm{Cu}_{1.5}\left(\mathrm{O}_{3} \mathrm{PCH}_{2} \mathrm{CO}_{2}\right) \cdot \mathrm{H}_{2} \mathrm{O}(\mathbf{1})$ CCDC-242268, $\mathrm{Cu}_{1.5}\left(\mathrm{O}_{3} \mathrm{PCH}_{2} \mathrm{CO}_{2}\right) \cdot \mathrm{H}_{2} \mathrm{O}(2) \mathrm{CCDC}-242269, \mathrm{Cu}\left(\mathrm{HO}_{3^{-}}\right.$ $\left.\mathrm{PCH}_{2} \mathrm{CO}_{2}\right) \cdot \mathrm{H}_{2} \mathrm{O}$ (3) CCDC-242270 and $\left[\mathrm{Cu}\left(\mathrm{HO}_{3} \mathrm{PCH}(\mathrm{OH}) \mathrm{CO}_{2}\right)-\right.$ $\left.\left(\mathrm{H}_{2} \mathrm{O}\right)_{2}\right] \cdot \mathrm{H}_{2} \mathrm{O}$ (4) CCDC-641330. Copies of the data may be obtained free of charge from The Director CCDC, 12 Union Road, Cambridge CB2 1EZ,UK(Fax, +44-1223-336033; e-mail, deposit@ccdc.cam.ac.uk; or Internet, http://www.ccdc.cam.ac.uk). This material is available free of charge via the Internet at http://pubs.acs.org.

\section{References}

(1) Hix, G. B.; Kariuki, B. M.; Kitchin, S.; Tremayne, M. Inorg. Chem. 2001, 40, 1477 .
(2) Hartman, S. J.; Todorov, E.; Cruz, C.; Sevov, S. C. Chem. Commun. 2000, 1213.

(3) Hix, G. B.; Turner, A.; Kariuki, B. M.; Tremayne, M.; MacLean, E. J. J. Mater. Chem. 2002, 12, 3220.

(4) Drumel, S.; Janvier, P.; Deniaud, D.; Bujoli, B. Chem. Commun. 1995, 1051.

(5) (a) Le Bideau, J.; Payen, C.; Palvadeau, P.; Bujoli, B. Inorg. Chem. 1994, 33, 4885. (b) Maeda, K.; Kiyozumi, Y.; Mizukami, F. Angew. Chem., Int. Ed. 1994, 33, 2335. (c) Maeda, K.; Kiyozumi, Y.; Mizukami, F. Chem. Commun. 1995, 1033. (d) Maeda, K.; Akimoto, J.; Kiyozumi, Y.; Mizukami, F. Angew. Chem., Int. Ed. 1995, 34, 1199.

(6) Riou-Cavellec, M.; Sanselme, M.; Guillou, N.; Férey, G. Inorg. Chem. 2001, 40, 723

(7) Rabu, P.; Janvier, P.; Bujoli, B. J. Mater. Chem. 1999, 9, 1323.

(8) Distler, A.; Sevov, S. C. Chem. Commun. 1998, 959.

(9) Drumel, S.; Janvier, P.; Barboux, P.; Bujoli-Doeuff, M.; Bujoli, B. Inorg. Chem. 1995, 34, 148.

(10) Ayyappan, S.; Diaz de Delgado, G.; Cheetham, A. K.; Férey, G.; Rao, C. N. R. J. Chem. Soc., Dalton Trans. 1999, 2905.

(11) Stock, N.; Stucky, G. D.; Cheetham, A. K. Chem. Commun. 2000, 2277.

(12) Cabeza, A.; Aranda, M. A. G.; Bruque, S. J. Mater. Chem. 1998, 8, 2479.

(13) Stock, N.; Frey, S. A.; Stucky, G. D.; Cheetham, A. K. J. Chem. Soc., Dalton Trans. 2000, 4292.

(14) Lis, T. Acta Crystallogr. 1997, C53, 28.

(15) Hix, G. B.; Wragg, D. S.; Wright, P. A.; Morris, R. E. J. Chem. Soc., Dalton Trans. 1998, 3359.

(16) Sanselme, M.; Riou-Cavellec, M.; Grenèche, J.-M.; Férey, G. J. Solid State Chem. 2002, 164, 354.

(17) Afonin, E. G.; Sergienko, V. S.; Aleksandrov, G. G. Zh. Neorg. Khim. 1998, 43, 1463 (in Russian).

(18) Ślepokura, K.; Piatkowskạ, A.; Lis, T. Z. Kristallogr. 2002, 217, 614.

(19) Cabeza, A.; Aranda, M. A. G.; Bruque, S.; Poojary, D. M.; Clearfield, A.; Sanz, J. Inorg. Chem. 1998, 37, 4168.

(20) Zakowsky, N.; Hix, G. B.; Morris, R. E. J. Mater. Chem. 2000, 10, 2375.

(21) Modi, R.; Hix, G. B.; Tremayne, M.; Maclean, E. New J. Chem. 2005, $29,427$.

(22) (a) Żurowska, B.; Brzuszkiewicz, A.; Ochocki, J. Polyhedron 2008, 27, 1721. (b) Jokiniemi, J.; Peräniemi, S.; Vepsäläinen, J. J.; Ahlgrén, M. CrystEngComm 2008, 10, 1011. (c) Kubíček, V.; Kotek, J.; Hermann, P.; Lukeš, I. Eur. J. Inorg. Chem. 2007, 333.

(23) Hooft, R.; Nonius, B. V. Collect: Data collection software; Delft: The Netherlands, 1998.

(24) Otwinowski, Z.; Minor, W. Methods Enzymol. 1997, 276, 307.

(25) (a) Blessing, R. H. Acta Crystallogr. 1995, A51, 33. (b) Blessing, R. H. J. Appl. Crystallogr. 1997, 30, 421.

(26) Sheldrick, G. M. Acta Crystallogr. 1990, A46, 467 (SHELXS, Software for structure solution).

(27) Sheldrick, G. M. SHELXL97, Program for crystal structure refinement; University of Göttingen: Germany, 1997.

(28) Farrugia, L. J. WinGX, A Windows Program for Crystal Structure Analysis; University of Glasgow: UK, 1998.

(29) We have observed a similar dehydration behavior in a Ca-HPAA material of an as of yet unidentified structure, but different from $\mathbf{4}$ (based on powder XRD): Demadis, K. D.; Papadaki, M.; Raptis, R. G.; Zhao, H. Chem. Mater. 2008, 20, 4835.

(30) (a) Demadis, K. D.; Katarachia, S. D.; Koutmos, M. Inorg. Chem. Commun. 2005, 8, 254. (b) Demadis, K. D.; Mantzaridis, C.; Raptis, R. G.; Mezei, G. Inorg. Chem. 2005, 44, 4469. (c) Demadis, K. D.; Katarachia, S. D.; Raptis, R. G.; Zhao, H.; Baran, P. Cryst. Growth Des. 2006, 6, 836. (d) Demadis, K. D.; Lykoudis, P.; Raptis, R. G.; Mezei, G. Cryst. Growth Des. 2006, 6, 1064. (e) Demadis, K. D.; Baran, P. J. Solid State Chem. 2004, 177, 4768. (f) Demadis, K. D.; Katarachia, S. D. Phosphorus Sulfur Silicon 2004, 179, 627. (g) Barouda, E.; Demadis, K. D.; Freeman, S. R.; Jones, F.; Ogden, M. I. Cryst. Growth Des. 2007, 7, 321. (h) Demadis, K. D. In Solid State Chemistry Research Trends; Buckey, R. W., Ed.; Nova Science Publishers, Inc.: New York, 2007; Chapter 5, p 109.

(31) Massiot, D.; Drumel, S.; Janvier, P.; Bujoli-Doeuff, M.; Bujoli, B. Chem. Mater. 1997, 9, 6.

(32) Brown, I. D.; Altermatt, D. Acta Crystallogr. 1985, B41, 244. 
(33) Li, J.; Meng, L.; Sun, Z.-G.; Cui, L.-Y.; Zhang, J.; Zhang, Y.-Y.; Dong, D.-P.; Chen, H.; You, W.-S.; Zhu, Z.-M. Inorg. Chem. Commun. 2007, 10,535 .

(34) Fu, R.; Zhang, H.; Wang, L.; Hu, S.; Li, Y.; Huang, X.; Wu, X. Eur. J. Inorg. Chem. 2005, 3211.

(35) Hix, G. B.; Carter, V. J.; Wragg, D. S.; Morris, R. E.; Wright, P. A. J. Mater. Chem. 1999, 9, 179.

(36) Kortz, U.; Marquer, C.; Thouvenot, R.; Nierlich, M. Inorg. Chem. 2003, 42, 1158

(37) Sun, Z.-G.; Chen, H.; Liu, Z.-M.; Cui, L.-Y.; Zhu, Y.-Y.; Zhao, Y.; Zhang, J.; You, W.-S.; Zhu, Z.-M. Inorg. Chem. Commun. 2007, 10, 283.
(38) Sun, Z.-G.; Cui, L.-Y.; Liu, Z.-M.; Meng, L.; Chen, H.; Dong, D.-P.; Zhang, L.-C.; Zhu, Z.-M.; You, W.-S. Inorg. Chem. Commun. 2006, 9, 999.

(39) Zhang, Y.-Y.; Zeng, M.-H.; Qi, Y.; Sang, S.-Y.; Liu, Z.-M. Inorg. Chem. Commun. 2007, 10, 33.

(40) Fu, R.; Xiang, S.; Zhang, H.; Zhang, J.; Wu, X. Cryst. Growth Des. 2005, 5, 1795

(41) Demadis, K. D.; Papadaki, M.; Raptis, R. G.; Zhao, H. J. Solid State Chem. 2008, 181, 679.

CG800992F 